This is a draft of a chapter that has been accepted for publication by Oxford University Press in the forthcoming book The Oxford Handbook of Islamic Law edited by Emon, Anver M. and Ahmed, Rumee, due for publication in 2016.

Accepted version downloaded from SOAS Research Online: http://eprints.soas.ac.uk/22402/

\author{
A Historiography of Islamic Family Law
}

Lynn Welchman, SOAS University of London, School of Law

Abstract

This chapter begins by reviewing two earlier historiographies of Islamic family law to illustrate the breadth and depth of the field. It then proceeds to examine the literature in three sections entitled What is Islamic family law? Who says so? And so what? The first section (what is it?) focusses largely on doctrinal scholarship on different substantive areas of law (including the contract of marriage, guardianship, dower, kafa'a, the spousal relationship, polygyny, divorce). The second (who says so?) considers the literature that deals with the different loci of authority to interpret, legislate and enforce Islamic family law, or parts of it; beyond the jurists and the body of fiqh literature, this involves notably the courts and the state, in differing relationships and formulations, as well as scholarship that argues that academics have no business determining what it is or is not and should rather be asking different questions. The third section (and so what?) considers literature that engages with the implications of the increasingly unsettled authority of apparently agreed-upon substance of Islamic family law, and the authority to pronounce thereon, that is, to say what it is. This growing body of scholarship engages with what Islamic family law could/should/might be and includes purposively engaged scholarship as well as examinations of activist alliances and the views of wider publics questioned about what they expect it to be - that is, what problems they expect this law to resolve.

There are many ways of going about a historiography of Islamic family law for the purposes of this volume. For manageability and access, this is a story of English-language scholarship and is mostly focussed on the Middle East and North Africa, although I also refer to scholarship on legal practice in Muslim majority states in South and South East Asia and Africa, and in Muslim communities in Western Europe and North America. For organizational purposes I approach the task with three questions in mind: What is Islamic family law? Who says so? And so what?

Two relatively recent historiographies of Islamic family law serve to orient my introduction. In 1999, Annelies Moors published a seminal reflection entitled 'Debating 
Islamic Family Law: Legal Texts and Social Practices' in a collection reviewing the state of scholarship on women and gender in the Middle East. ${ }^{1}$ Framed as a response to the 1968 claims of Anderson on 'The Eclipse of the Patriarchal Family in Contemporary Islamic Law', Moors' review shows how the debates have been opened up by the entry into the field of differently placed scholars - notably women, and even more notably women from the region, and from disciplines other than law and what was then called Oriental Studies, such as those working in women's and gender studies, anthropology and history. The debates she covers focus on challenges to the idea of the traditional Muslim family, monolithic, unchanging, patriarchal, governed by the text of Islamic family law as understood from classical fiqh texts. The challenges are made through examination of different sources, including evidence of social practice as found in court records, fatwas and oral narratives. They show women in history exercising agency within the given framework, going to court, mobilising resources, negotiating, controlling property, and they seek to identify women's voices in the telling of this history.

Moors identifies this shift in perspectives to the late 1970s, and goes on to consider the role of the state, the relationship between the exigencies of post-colonial state-building, the construction of ideal family types as reflected in national codifications of Muslim 'personal status law' (a term which Cuno shows to have entered Egyptian legal terminology via French colonial practice in Algeria ${ }^{2}$ ) and citizenship expectations and aspirations. She looks at the state's organisation of its judiciary, the attitudes of the judiciary, at 'Islamic modernity', the rise of political Islam and 'Islamic feminism', women's activism and the impact of and on family law of all these, as debated in the scholarship she reviews. To these areas - all still attracting scholarly interest - I would add the burgeoning scholarship on international human rights law and Islamic family law. Moors' focus on gender as a lens through which to examine Islamic family law scholarship matches the development of gender as a theoretical construct more generally. Of particular significance here is historian Judith Tucker's Women, Family and Gender in Islamic Law, published as one of the 'themes in Islamic law' series edited by Wael Hallaq and intended "to interpret the complexities of the subject for those entering the field for the first time." ${ }^{3}$ The book is thus a landmark - and a considerable achievement - in applying feminist legal theories and gender analysis to the historical articulations and current narratives of Islamic family law in a monograph intended as an introductory account of the substance. Appropriately, Tucker joins the more recent pattern of scholars in entering the text in the first person.

The second historiography, this time from a law and society perspective, comes from Susan Hirsch in 2006. Although a broader overview in that it looks at scholarship in Islamic law more generally (that is, not only family law and not only in the Middle East), the bulk of this review is on family law as "the substantive area of Islamic legal practice most prevalent in the world today." Hirsch situates her review in the post-9/11 world, reflecting on the

\footnotetext{
${ }^{1}$ Moors in Meriwether and Tucker (1999). Anderson 1968.

${ }^{2}$ Cuno 2015.

${ }^{3}$ Tucker 2008.

${ }^{4}$ Hirsch, 2006165.
} 
impact of those events on scholarship as well as on popular discourse and arguing that this scholarship "speaks to the thorny social and political challenges" post 9/11. ${ }^{5}$ She finds an emphasis on diversity in the practice of Islamic family law, and argues that the scholarship has as much value in its contribution to wider social theory as to the specific understandings of Islamic law. This stand against academic exceptionalism invokes the scholarship of Dupret and others reviewed here later. Hirsch begins with what she refers to as 'source books', one edited by An-Na im within the framework of a larger project looking at the application of IFL in different parts of "a changing world", and introduced by An-Na im with a "plainly stated reformist agenda"; and the other by the network Women Living Under Muslim Laws with a specifically activist agenda, evaluating different applications and understandings of IFL with a view to suggesting which positions in state laws are more or less protective of women's rights. ${ }^{6}$ Hirsh goes on to look inter alia at scholarship focussing on Islamic family law as one among other "competing normative orders", at gender identity construction and intersectionality, at ethnographic work looking at women's agency in and indeed beyond courts applying Islamic family law, at social movements advocating for law reform and at scholarship on Islamic family law practices in non-Muslim majority states.

As should already be clear, then, English language scholarship on Islamic family law currently includes a variety of academic disciplines and methodologies, geographical focuses, and substantive themes. Some of the scholarship focuses on family law issues to explore another primary theme - for example, in historical work, the early origins and development of fiqh; or in contemporary ethnographic work, the way women use courts. Outstanding examples of this in edited collections in the 'Islamic law' discipline are the volumes on Islamic Legal Interpretation (on muftis and fatwas) ${ }^{7}$ and Dispensing Justice (on judges and the courts). ${ }^{8}$ Outputs focused specifically on family law include monographs, articles (published in range of journals beyond the field of Islamic studies or indeed comparative law), edited collections on themes and geographical regions, websites, manuals for practitioners, multi-party collaborations and documentary films. Audiences, beyond academia, include policy makers and the wider public, Muslim and non-Muslim thinkers, activists and citizens. All of which brings us to the first question posed: what is Islamic family law?

\section{What is it?}

Substantively, Islamic family law covers the heterosexual spousal relationship (marriage, its conduct and its termination by death or divorce), the parental relationship (legal recognition of the parent-child relationship or affiliation or legitimacy of birth and rights and obligations arising therefrom, child custody and guardianship), succession (although this is

\footnotetext{
${ }^{5}$ Hirsch 2006166.

${ }^{6}$ Hirsh 2006 172; An-Na`im 2002; WLUML 2003. See also Welchman 2004.

${ }^{7}$ Masud, Messick and Powers (1996). See in this volume Motski, Masud, Haeri, Vogel, Layish.

${ }^{8}$ Masud, Peters and Powers $(2006,2012)$. See in this volume Stiles, Bowen, Dupret, Johansen, Fierro, Masud, Powers.
} 
often treated separately and will not be included here), and other family relationships in so far as they give rise to legally-regulated rights and obligations such as maintenance and responsibility for minors.

The classical jurists did not write of 'family law' as a distinct category; indeed, as no doubt explained elsewhere in this volume, the lack of distinct categorizations of substantive areas of law such as 'contract' and 'family', setting out a body of law recognizable as such by imperial and colonial visitors from other (Western, notably French and English) legal systems, was one of the reasons that fiqh was found to be, somehow, not quite 'law'. I discuss further below scholarship on the entanglement of Islamic family law with the modernity discourses of colonial and imperial powers and modernizing elites in different states, and implications for the state-endorsed structure of the Muslim family. To begin with doctrine, however, an appropriate place to start is with the family law section of Issues in Islamic Law, the second of a recent three-volume collection of "the best and most influential contributions" to the debates on Islamic law edited by Mashood Baderin and situated by the publishers in the context of increased attention to Islamic law after the events of 9/11. ${ }^{9}$ The scholarship selected by Baderin in this volume presents the 'classical' fiqh debates and positions - in some cases as background to a comment on a recent development or change - on the marriage contract, the wife's right to dower from her husband, the concept of kafa' $a$ (equality) required of the husband, marriage guardianship, the marital relationship, polygyny, and divorce. ${ }^{10}$ The scholarship thus mostly comprises doctrinal examination of the sources and the differences between the schools on particular issues in Islamic family law.

\section{Marriage Contract Law and Doctrine}

Baderin's selection includes some 'classic' older pieces as well as more recent articles, and thus illustrates the ways in which doctrinal approaches have developed. The first piece in the collection, for example, is a very short overview of marriage in Islamic law with an update on $20^{\text {th }}$ century reforms in MENA states, and opens with an explanation of how pre-Islamic marriage law and practice (among Hijazi Arabs) was reformed by "the new law under Islam - the Shari a", specifically looking at Qur'anic provisions on the family that became the basis for fiqh formulations of the family. ${ }^{11}$ Khadduri's consideration of the limitation on polygyny in particular takes us to the debate as to whether these changes to preexisting practice in the particular Hijazi context of the revelation were meant to coalesce into a fixed doctrine for all time and place, or whether, as he suggests, it was as far as it was possible to go at that time and place: "[ $\mathrm{t}]$ he ultimate intent of Quranic marriage law, then, was to legitimate monogamy, rather than to endorse polygamy."12 Reformist thinkers have focused on the importance of context in reading these and other Quranic verses related to the

\footnotetext{
${ }^{9}$ Baderin 2014.

${ }^{10}$ Khadduri 1978, Anderson 1950, Ziadeh 1957, Siddiqui 1995, Carroll 1987, Hinchcliffe 1970, Kola 2010,

Ahmad 2009, Khan 2009 and Welchman 2011.

${ }^{11}$ Khadduri 1978213.

${ }^{12}$ Khadduri 1978217.
} 
family, ${ }^{13}$ Leila Ahmed, in a highly significant text, makes a case for a different view of preIslamic history and argues that women's rights in general (and in the family in particular) were constrained (against the spirit of the Qur'an) during the first few centuries of Islam through the jurists working in their own context and time. ${ }^{14}$ And to see how the task of setting out the basic rules on Muslim marriage is approached in $21^{\text {st }}$ century scholarship, look no further than the fine contribution by Kecia Ali to the excellent 2008 collection on The Islamic Marriage Contract; Ali does the field a great service in setting out the basic rules on marriage in classical fiqh, indicating main differences between the four Sunni schools and Ja afari doctrine. $^{15}$

Baderin's second choice is a classic article by JND Anderson, an in-depth presentation of "one of the most bewildering problems in Muslim law", that is "the classification and effect of various types of invalid marriage contract", ${ }^{16}$ focusing here on the differences within the Hanafi school on which type of contract belongs in which category (void or invalid/irregular), why and with what legal effects. Anderson has already been mentioned above in reference to Moors' critique of his article on the 'eclipse of the patriarchal family.' Of the relevant scholars of Islamic law writing in the West in the 1950s1970s and whose scholarship is often characterised as 'Orientalist' in the Saidian sense, ${ }^{17}$ it was JND Anderson who wrote most prolifically on Islamic family law. In particular, it was Anderson who followed the codifications of family law issued by independent Arab states in the 1950s in what I have called the second phase of Muslim family law reform. ${ }^{18}$ This part of Anderson's body of work is still quoted in contemporary scholarship looking at text and court application; ${ }^{19}$ and it is worth remembering that it was considerably more difficult then to physically get hold of new legislation from different parts of the world. In retrospect of course, this body of work presents as 'looking for shari 'a in the law,' as compared to the traditional jurists 'looking for law in the shari ' $a$ ', and presumably falls foul of Dupret's admonition, discussed further below (under 'who says so?), with regard to scholars judging what is and is not 'Islamic' in law and legal practice. ${ }^{20}$

Anderson's tone is distinctly of its time, but his much-quoted observation in regard to family law, that "Muslims have regarded that law as partaking most closely of the very warp and weft of their religion," 21 goes to the familiar and current assertion that family law is inextricably tied up with religion in Muslim communities. This assumption has recently been challenged by Cuno's historical examination of the development of the relationship between Muslim family law and the state in Egypt from the late $19^{\text {th }}$ century, in particular judicial

\footnotetext{
${ }^{13}$ See Mir-Hosseini 200311.

${ }^{14}$ Ahmed 1992.

${ }^{15}$ Ali in Quraishi and Vogel (2008). For an older text on the contract see El Alami 1992.

${ }^{16}$ Anderson 1950357.

${ }^{17}$ Said 1978.

${ }^{18}$ Welchman (2007); Anderson 1950, 1951, 1952, 1955, 1960. Jeppie, Moosa and Roberts (2010) identify Anderson's Islamic Law in Africa as his first major publication and note that he "took the colonial context for granted" (p.21).

${ }^{19}$ See Van Eijk (2012).

${ }^{20}$ Dupret 2006, 2007.

${ }^{21}$ Anderson 1976 p.17.
} 
reorganisation and the consequent reduction in jurisdiction of shari 'a courts. Cuno finds that "the close association of the family with religion and religious law" was "a contingent development and neither inevitable nor an expression of 'the centrality of the family in Islam,' as often claimed. [...] Colonial scholarship produced the idea that family law is the 'heart' of the Sharia." 22 Neither the fact that public opinion surveys carried out in certain Muslim majority countries suggest a preference for "shari 'a-based" law in family regulation, nor scholarship on the conduct of 'Islamic marriages' in minority Muslim communities in the West, necessarily detract from Cuno's assertion that this is how colonial modernity has fixed the relationship.

Anderson's article commences with an examination of Abu Hanifa's views of contracts other than the contract of marriage, to show that the latter applied "exactly the same principles and method of reasoning" to the contract of marriage: Abu Hanifa was, according to Anderson, "relentlessly logical". ${ }^{23}$ The issue of the validity of the contract is of enormous importance: "Marriage is a contract of civil law" according to Schacht, and "[ $\mathrm{t}]$ his contract is the only legally relevant act in concluding marriage." 24 In other words, it is not a sacrament and no religious ceremony (alone) or the involvement of religious personnel constitutes or are required for the valid performance of this contract. Nevertheless, Mir-Hosseini notes that while the legal form of marriage is dealt with under the status of mu amalat (social transactions), jurists "often speak of marriage as an act of worship ('ibada)", thus making marriage "one of the very few contracts in fiqh that crosses that boundary between 'ibadat and mu amalat". ${ }^{25}$ For Mir-Hosseini, this is tied up with the social context in which the jurists were reading the revelation, and has consequences for the way in which rules regarding women and gender more generally - but particularly in the family - were and are constructed by jurists down the centuries, and how arguments against changes in these rules are framed now, how ideas of normativity develop among different communities. These angles were not of such interest to Anderson or his peers, although Fyzee insisted on this point (marriage being both mu 'amala and 'ibada) from the perspective of a practitioner. ${ }^{26}$

\section{The Mahr: Contract, Property and Gender}

The wife's right to dower - arising at and from the contract, although also connected with consummation - is a matter that has drawn the attention of scholars interested beyond the law as narrowly interpreted as it illustrates women's access to property, the transfer of property through generations and social practice in different times and places as evidenced by various forms of records. Thus Rapoport investigates extant early Islamic marriage and divorce deeds in Egypt from the $8^{\text {th }}$ century CE onwards as well as the jurists' discussions on

\footnotetext{
${ }^{22}$ Cuno (2015) 183-4; citing (critiquing) Esposito with Delong Bas (2001) xiv.

${ }^{23}$ Anderson 1950 358, 357.

${ }^{24}$ Schacht 1964 p.161.

${ }^{25}$ Mir-Hosseini 2003 11. See also Kecia Ali (2008); Tucker (2008) 41; Sonbol (2008) 114; Shaheen Ali 1996162 ; Lindbekk 2014; Fyzee 1974 89-90.

${ }^{26}$ Fyzee 1974, 89-90.
} 
the validity of deferral of part of the dower, ${ }^{27}$ comparing this Egyptian position to those taken by jurists elsewhere to establish a link with social practice. Rapoport argues that evidence of an increasingly common practice of recording deferred dower undermines arguments (here he cites Ahmed) that the second and third centuries of Islam were detrimental to the position of women. ${ }^{28}$ At the same time, he examines matrimonial gifts more broadly, including among Jews and Copts in Egypt, to make a broader argument about "the interaction of nascent Islamic law and local marriage practices" which he finds to have "influenced and transformed both the views of Muslim jurists and the actual marriage settlements". ${ }^{29}$

Women's access to property through dower (as well as through inheritance) has also been investigated in depth since the 1990s. Moors traces dower patterns in Jabal Nablus in Palestine over the course of the twentieth century, tracing an increase in deferred dower over prompt and the rise of the token dower, an "innovation of the modernizing elite" 30 although accompanied by the increasing registration of household goods and gold. Attending to differences between women (social class and employment, as well as urban/rural differences) and drawing on oral narratives as well as court records and legal texts, Moors investigates discrepancies between the dower registered in contracts and that actually received by the bride. This involves not only the earlier practice of the bride's father retaining a proportion of the dower, ${ }^{31}$ but the reasons why wives do not necessarily claim their full dower from their husbands or, in the case of widows, renounce their deferred dower in favour of their children (in cases where they have at least one son). Moors situates changes in dower patterns in "the context of changing property relations and changes in the meanings of gender," ${ }^{, 32}$ with increasing emphasis on the conjugal family and a growing emphasis on the husband as provider. In company with other scholars, Moors has shown how women from different classes use the institution of dower within informal strategies for the protection of their rights including protection against divorce from their husband, or in support of their own demand for divorce. ${ }^{33}$ In Iran, where law requires that a cash amount of dower is to be adjusted to allow for inflation, Mir-Hosseini similarly observes the way the wife may exercise her right to demand payment of her dower in order to persuade a husband to divorce her, or to agree to other changes that she wishes to see in her marriage. ${ }^{34}$

The issue of dower has also been a focus of scholarship examining the way in which courts in non-Muslim majority countries deal with Islamic family law, a body of work that has grown as the case law grows. Pascale Fournier's Muslim Marriage in Western Courts lucidly examines the meanings of dower as it 'travels' to courts in North America, France and Germany. ${ }^{35}$ Lau and Freeman trace the earliest leading case in English law to 1965 and note the preference of English courts to invoke principles of contract law rather than matrimonial

\footnotetext{
${ }^{27}$ Rapoport 2000.

${ }^{28}$ Rapoport 200021.

${ }^{29}$ Ibid p 4.

${ }^{30}$ Moors 1995 309. See by contrast Wynn (2008).

${ }^{31}$ See also Stiles 2014.

32 Moors 1995325.

${ }^{33}$ Moors 1995; Wynn 1996; Hoodfar 1996; Mir-Hosseini 1993 72-83.

${ }^{34}$ Mir-Hosseini 2007 120. See also Longinotto and Mir-Hosseini (1998).

${ }^{35}$ Fournier (2010). See also Yassari (2013); Jones-Pauly (2008); Quriashi and Syeed-Millar (2004) 200-208
} 
law in such cases. ${ }^{36}$ Quraishi and Syeed-Miller note that in Muslim marriage contracts in the US, there seems to be "only one thing really important that would not otherwise be included in a standard civil marriage licence"- that is, the dower. ${ }^{37}$ Their examination includes the social debate as to whether dower should be rejected (or converted into a 'token') because in effect it puts "a monetary value on the bride", or whether it should be seen rather, as in the case of deferred dower, as security for the eventuality of death or divorce and as a deterrent against unilateral divorce. ${ }^{38}$ This discussion has also been common in the Middle East and North Africa; in Algeria, Lazreg notes that despite feminists holding dower to be "an antiquated custom that objectifies women" it remains a major feature of marriage. ${ }^{39}$ Calls of different groups are recorded for dower to be reduced particularly in critical periods of national history, while scholarship maps ways of subverting officially decreed upper limits on dower. ${ }^{40}$ While law may regulate what can be claimed in court from whom and when, scholarship increasingly confirms that social practice and strategic action provide the real meanings of dower. ${ }^{41}$

\section{Kafa'a: Suitors, Suitability, and Stratification}

Other requirements arising at the contract of marriage have also attracted scholarly attention that departs in its framing (and sometimes its findings) from earlier considerations of these areas of Islamic family law. Farhat Ziadeh opens his early piece on the concept of $k a f a$ ' $a$ (suitability, or equality as Ziadeh has it) by observing that perhaps "no criterion is more indicative of social stratification among a group than that of whom they consider equal to, and therefore worthy of, marrying their daughters". ${ }^{42}$ This encapsulates two key points in regard to kafa' a: firstly, it is a measure that distinguishes between otherwise apparently equally situated Muslims, and secondly that it "requires the husband to 'measure up' to the wife and not vice versa." ${ }^{, 43}$ Kafa' $a$ is originally a Hanafi doctrine and attributed to the influences of the social environment in Iraq in which early Hanafi jurists were working. Looking into the early jurisprudential debates and the sources invoked for and against the doctrine, Ziadeh finds that "there can be no doubt that there is a preponderance of evidence to show that kafa'ah is contrary to the spirit of Islam."44 This again invokes more recent scholarship arguing that many fiqh rules on marriage were developed as a result not of the substance of revelation but of the jurists' own living and working environments.

At the end of his piece Ziadeh provides two famous cases regarding kafa' $a$ in the early twentieth century, one in Egypt and one from the Alawi community in Singapore.

\footnotetext{
${ }^{36}$ Lau and Freeman (2008).

${ }^{37}$ Quraishi and Syeed-Miller (2004) 188.

${ }^{38}$ Ibid 189.

39 Lazreg 1994 181-82. See also Dahlgren 2005 137-140; and Mir-Hosseini 199332.

${ }^{40}$ Badran 1995 139-40; Wing 1994 188-89; Wurth 200313.

${ }^{41}$ See Moors 2008.

${ }^{42}$ Ziadeh 1957503.

43 Ibid 509.

${ }^{44}$ Ibid 508.
} 
Although he finds (in 1957) that as a legal doctrine, $k a f a$ ' $a$ has waning force, it is included in reduced form in different formulations of family law codes in Arab states. Kafa'a applies at the time of the contract, and as Khalid al-Azri explains in a recent and in depth study, it is closely connected with the authority of the guardian; in his view, "guardianship and kafa' $a$ exist to control the aptitude of a woman in her marriage selection." A1-Azri's examination of kafa' $a$ includes jurisprudential analysis of diverse opinions on kafa'a between and among Sunni schools and Ibadi scholars (the Shi a do not recognise it ${ }^{46}$ ) as well as social perceptions (including a lively internet discussion) and court practice in Oman. He sets his discussion clearly in the social and political context, traces cases through court records to show judges coming to different conclusions on how to apply the doctrine, considers the background and training of different judges and the tensions between Ibadi doctrine, the Omani Personal Status Law, and the Basic Law's guarantee of non-discrimination on grounds of (inter alia) gender, origin and social status. Another recent contribution to the scholarship on kafa'a comes from Malaysia, where Noor and Lee trace acrimonious debates in the early $20^{\text {th }}$ century between members of the Hadrami-origin Arabs divided into sayyids (claiming descent from the Prophet) and non-sayyids. ${ }^{47}$ The former applied the principle of kafa' $a$ to restrict sayyid women to marriage with sayyid men only, excluding other Arabs as well as everybody else; the non-sayyid community objected on the grounds of the general principle of equality in Islam, while in some reported cases objecting to women from their own community marrying non-Arabs.

\section{Wilaya: Guardianship, Agency and Gender}

The broader notion of male guardianship over women is seen by some Muslim feminist scholars as part of the "DNA of patriarchy" in fiqh ${ }^{48}$ Marriage guardianship over minors and in some cases over adult women was an issue much discussed among the classical jurists and is immediately connected with the issue of consent: whether the woman needs her guardian's to her marriage, and whether he needs her consent to marry her off. ${ }^{49}$ The Hanafi and the Shi a traditionally allowed adult women to contract their own marriage without the guardian's consent, and this theoretical position has been substantiated by social historians who have found evidence of women exercising this right at different times and in different places - with the support of courts and muftis while in opposition to social practice and customary expectations. ${ }^{50}$ Social norms in different Muslim communities may continue to expect a woman, particularly at her first marriage, to have the approval of her family guardian, whether or not this is required in law. Stiles' recent ethnographic work in and beyond a Zanzibari shari $a$ court explores the increasing willingness of young women to take their fathers to court demanding the right to marry the man of their choice; Stiles' interest lies also in exploring the impact of a greater awareness of Islamic law on the part of young

\footnotetext{
${ }^{45}$ Al-Azri 2010, 2013 p.39.

${ }^{46}$ Ibid 38.

${ }^{47}$ Noor and Lee 2013.

${ }^{48}$ Mir-Hosseini 201535.

${ }^{49}$ Carroll 1987.

${ }^{50}$ See Tucker 1998 50-51
} 
women in decisions both to challenge their elders and to refrain from so doing. ${ }^{51}$ In Pakistan in the 1990s, considerations by Ali and Lau of a widely publicised case on a woman's right to marry without her guardian's consent situate the court's deliberations not only in terms of Hanafi law and statutory interventions but the ways in which judges' statements reflected the primacy of social expectations beyond the letter of the law. ${ }^{52}$ The case involved the young woman fleeing to a women's refuge following her father's attempt to have her marriage contract cancelled; the case was raised by the father against the refuge for abduction. The challenge to familial and social expectations of the guardian's involvement in a woman's marriage, and woman's "right to marry", thus entangle different bodies of law and different social actors, which scholarship now addresses also in terms of constitutional guarantees of equality and habeas corpus in a human rights perspective. ${ }^{53}$

On the other hand, the marriage of minors (where legal consent to the contract is given by the guardian) has been a continuing focus of historical scholarship, often examining the 'option of puberty' which under Hanafi law could be exercised by a female married in her minority by a guardian other than her father or paternal grandfather to exit a marriage upon reaching puberty. Messick's account of a young woman doing precisely this in mid-twentieth century Yemen, reconstructed from a series of court records, is an arresting account of how the rules and gendered assumptions of female behaviour in this regard played out "in the last decades of Shari a law application under an indigenous Islamic state. ${ }^{, 54}$ Messick also observes that the young woman involved "must have had good legal advice", while Motzki suggests on the basis of evidence from $17^{\text {th }}$ century Palestine, to the effect that the option of puberty was commonly invoked, that there was widespread awareness of this rule. ${ }^{55}$ Yazbek agrees, also working on the Palestine court records but in the 19th century, reflecting on the "weight of the male gaze" in the records, speculating as to what strategies were involved in bringing cases to court, and wondering at explicit descriptions by (only just) pubescent girls of sexual intercourse and menstruation. ${ }^{56}$ Tucker considers the apparently straightforward position of Hanafi muftis supporting the need for an adult woman's consent to her marriage compared to court cases, in seventeenth and eighteenth century Ottoman Syria and Palestine, to wonder about the extent to which social norms of male control were actually accommodated in practice while the formalities of the woman's consent were attended to in the written record. ${ }^{57}$ On the other hand, she has also noted that the "seemingly widespread practice of appointing mothers as guardians in the Ottoman period is one more instance of the society's view of women as appropriate and competent managers of private property. $" 58$

The marriage of minors is statutorily less countenanced now, but the $21^{\text {st }}$ century witnessed a rise in scholarship (as well as advocacy) on "forced marriage", drawing on and

\footnotetext{
${ }^{51}$ Stiles 2014.

52 Ali 1996, Lau 1996.

${ }^{53}$ See for example Hossain 2011.

${ }^{54}$ Messick 2008160

${ }^{55}$ Messick 2008 175; Motski 1996139.

${ }^{56}$ Yazbek 2002398.

${ }^{57}$ Tucker 2008.

${ }^{58}$ Tucker (2008) 157.
} 
contributing to wider concepts of choice, consent and coercion. ${ }^{59}$ While in the UK for example the scholarship insists on not making this a 'Muslim issue', Bano uses the example of the role of the Muslim Arbitration Tribunal to consider the implications more broadly of "the increasing privatisation of disputes," feeding into a wider debate on the use of mediation mechanisms in situations of serious power imbalances. ${ }^{60}$ The South Asian country studies in Hossain's 2014 handbook for lawyers include background on the statutory regulation of Muslim marriage (as well as Christian and Hindu marriage), including the position on minor marriage, as well as constitutional guarantees, civil and criminal remedies for forced marriage. ${ }^{61}$

\section{Polygyny, Divorce, and Pluri-Legality}

Similarly, Islamic family law rules on polygyny and divorce are increasingly addressed in scholarship invoking not only Islamic family law rules and statutory developments in different states but also international human rights law. ${ }^{62} 21^{\text {st }}$ century scholarship may focus on the fact that polygyny and unilateral divorce (talaq), as prerogatives of men, are easily framed as contradicting the norms of equality and nondiscrimination. An example of earlier scholarship that did not refer to this frame is provided by Hinchcliffe (1970), while Mashour's 2005 article illustrates the distance (and the direction) that scholarship in this area travelled in three and a half decades - not least the fact that the latter piece is published not in a journal focussing on Islamic law or Muslim matters more generally but in an established human rights journal and includes "gender equality" in its title. ${ }^{63}$ A recent piece from South East Asia notes proposals for reform to Malaysian law and procedure by women's groups but focuses on controlling abuse of the institution, notably by men who engage in 'forum-shopping' to avoid the involvement of their existing wife in the procedures to obtain permission for a polygynous marriage, or who cross national borders to conclude contracts under different rules, or who simply fail to register them. ${ }^{64}$ Yamani's study of polygyny in Saudi Arabia includes legal analysis of both the classical Sunni law and Saudi regulations and beyond this provides an explicitly "insider" perspective on this debate, including an examination of the "nationalist, Islamic, political debate, which automatically labels any form of regulation of the practice and its management as a sign of heresy, a mark of joining in with the anti-Islamic Western conspiracy.",65

Legal pluralism analyses address not only unregistered polygynous marriages in parts of the Muslim world but also polygynous unions among Muslim communities in Western states; Shah for example examines English court cases in support of his broader argument that "a dominant legal system is ill-advised to attempt to impose a mono-cultural and ethno centric regime upon a legally pluralist social base." ${ }^{66}$ Elsewhere in the Middle East and North

\footnotetext{
${ }^{59}$ See for example Gill and Anitha 2011; Siddiqui 2011. More broadly see Abu-Lughod and Rao 2011.

${ }^{60}$ Bano (2011) 177.

${ }^{61}$ Warraich (2014), Hossain (2014), Lawyers' Collective (2014). See also in the UK Arshad (2010) 64-87.

62 See Rehman 2007.

${ }^{63}$ Hinchcliffe (1970); Mashhour (2005). But see also Siraj 1964.

${ }^{64}$ Kamaruddin and Abdullah 2008.

${ }^{65}$ Yamani 200833.

${ }^{66}$ Shah 2007 370. See Yilmaz 2005.
} 
Africa, polygyny has been treated through a consideration of the restrictions imposed by statute and the connected issue of registration requirements. ${ }^{67}$ Najjar's discussion of the public and parliamentary debates on the 1979 Egyptian law's option of divorce for a first wife without having to prove harm, but rather from the bare fact of a polygynous marriage by her husband (a provision withdrawn in 1985) was a relatively early contemporary foray into documenting the environment surrounding particular legislative reforms; this kind of effort is of course facilitated in more recent times by social media, on-line records and other electronic resources. ${ }^{68}$

Besides its highly gendered nature, Islamic family law regulation of polygyny is connected to the rules on divorce through the recurring issue of stipulations in the marriage contract: and in particular, stipulations securing the wife a delegated power of talaq either in general terms or in the event that a husband contracts a polygynous union or other formulations seeking to prevent the husband from so doing. Some of the most interesting scholarship on the delegation to the wife of the husband's power of talaq relates to South Asian jurisdictions. The dominance of the Hanafi school, with its very restricted grounds on which women could petition the court for judicial divorce, is the context of Khan's consideration of a fatwa from a prominent Indian jurist in the early 1930s on the need for reform in divorce law. ${ }^{69}$ The regional context included the validity of Muslim wives using apostasy from Islam as a "legal device" to dissolve their marriages in the absence of other options. This was a strategy encouraged by certain Christian missionaries, an issue discussed in depth by Masud who notes that "[i]t was this fatwa that triggered the movement for Islamic legal reform in India" leading eventually to the Dissolution of Muslim Marriage Act $1939 .{ }^{70}$ Khan examines the part of the fatwa dealing with the husband's delegation of talaq to his wife, and includes an incisive and very $21^{\text {st }}$ century reading of Thanawi's "important counsel" on "women's intellectual deficiency". ${ }^{71}$ Somewhat similar procedural rules were included in Fyzee's 'Agreement for Dissolution of Marriage' which was drafted in the 1960s with his assistance by a Bombay solicitors' firm "at the instance of" a woman whom Fyzee describes as "a prominent worker in the cause of women's rights." ${ }^{\text {"72 }}$ Recalling this in her own 1982 consideration of delegated divorce, Carroll notes the continuing utility of this approach at contract in India, Pakistan and Bangladesh: "the grounds on which the wife is authorized to exercise her delegated right of divorce are so broad that the matrimonial power-balance in regard to dissolution of marriage is substantially equalized." ${ }^{, 73}$ Carroll's article on stipulations in the marriage contract focuses mostly on stipulations against polygyny and for delegated divorce, but she also looks at other stipulations for example on post-divorce maintenance and the residence of the spouses, and her piece tracks how the different rights and obligations arising from the contract arise in interaction with special stipulations. She examines Indian cases from the early twentieth century and how the courts invoked the requirements of

\footnotetext{
${ }^{67}$ Wurth 2003; Mitchell 1997; Welchman 2007 77-87; Anderson 1976 61-64.

${ }^{68}$ Najjar 1988. See Bernard-Maugiron 2008.

${ }^{69}$ Khan 2009.

${ }^{70}$ Masud 1996 p 196.

${ }^{71}$ Khan 2009 514-516.

${ }^{72}$ Fyzee 1974.

${ }^{73}$ Carroll 1982 303-05 at p.304.
} 
'public policy' to (often) uphold the wife's stipulations, coming up to date with more recent cases and concluding with the space provided in Pakistani and Bangladeshi marriage registration forms for such conditions to be included, noting a lack of information on whether and how such options have been exercised. ${ }^{74}$ Her article has the advocate's engagement: she wonders "what, if any, efforts women's organizations are making to popularize the use" of Fyzee's model agreement. ${ }^{75}$ Later in the following decade, Carroll worked with the network Women Living Under Muslim Laws (WLUML) to publish a "toolkit" on delegated divorce. ${ }^{76}$ The engagement of scholars and activists, in particular in regard to women's rights and options and with a view to a different constituency and audience for this scholarship, is discussed in the third section below ("So What?"), but it is worth noting here that Carroll and WLUML also treated the complex issue of a wife's post-divorce maintenance in a collection issued on the tenth anniversary of the famous Indian case of Shah Bano. ${ }^{77}$

Another region-specific issue is that of triple talaq, by which a husband ends his marriage finally and irrevocably, and requiring an intervening marriage by the wife should the couple wish to re-marry. Ahmad's 2009 "critical appraisal" of this "abominable practice" by Muslim husbands in India investigates mainly the "Qur'anic philosophy" on divorce, sources from the hadith of the Prophet and the early caliphs and jurists. ${ }^{78}$ The sources invoked, and the tone of insider outrage, distinguish this doctrinal piece for a more general audience. On the other hand, in the Middle East and North Africa, where codifications of family law have mostly dealt with the challenge of triple talaq by rendering such formulae as a single revocable divorce, Agmon has suggested from her reading of late Ottoman court records that "many marital disputes [...] give us the impression that women sometimes found ways to provoke their husbands into making the talaq call, thus obtaining the divorce". ${ }^{79}$ Moors similarly includes the abolishing of conditional and triple talaq as examples of reforms that "do not always work to women's benefit; in the past, women have made selective and strategic use of these in order to bring about a desired divorce."

Historians have demonstrated that women's access to divorce was considerably wider in court practice than might have been assumed under ruling authorities that privileged Hanafi fiqh. Tucker's evidence shows that muftis would recommend that a Hanafi judge transfer the case to a deputy from another Sunni school who would grant a divorce on grounds not available from the Hanafi sources. ${ }^{81}$ Abdal-Rehim's study of Egyptian court records from the late $16^{\text {th }}$ century includes examples of khul divorce, in traditional fiqh a form of divorce initiated by the wife who in return for the husband's talaq renounces her remaining financial rights (maintenance and deferred dower) and sometimes repays dower already received. Particularly noteworthy here is his finding that the judge would enforce a

\footnotetext{
${ }^{74}$ Carroll 1982308.

${ }^{75}$ Carroll 1982305.

${ }^{76}$ Carroll 1996

${ }^{77}$ WLUML 1998; and see Holden (2013).

${ }^{78}$ Ahmad 2009 p.59, 54.

${ }^{79}$ Agmon 1996136.

${ }^{80}$ Moors 1999 155-56. See also Layish (1975) 175.

${ }^{81}$ Tucker, 1998 78-112;
} 
khul petition from the wife "even when the husband was not willing to go through with it." Other historians, examining evidence from different times and places, disagree. ${ }^{83}$

The issue of "judicial khul", in the sense of a khul divorce pronounced by the court in the absence of consent from the husband, has been addressed by doctrinal scholarship on the Middle East and North Africa since the Egyptian law of 2000 providing for this form of divorce; scholars of South Asian law had dealt previously with the 1967 Pakistani precedent establishing judicial $\mathrm{khul}^{84}$ Arabi provides an in depth consideration of relevant Maliki rulings and the constitutional developments in Egypt that he argues led to the promulgation of this law; ${ }^{85}$ others have noted the sheer length of time it took to press a claim for judicial divorce through the Egyptian court system. ${ }^{86}$ The title of Arabi's piece indicates what he clearly considers the momentous nature of this legislative intervention as well as something of the tenor of public reaction ("women may divorce at will"); Sonneveld says that "the Egyptian nation was rocked" by the new law; El Alami calls it "nothing short of revolutionary". ${ }^{87}$ Scholarship on khul and indeed other forms of divorce in the Muslim world has deployed new methodologies and new theoretical frames that are discussed further below (“Who says so?”).

\section{Authority and the Marital Relationship}

Male prerogative in traditional figh on divorce has been identified as a key part of the overall conception of male authority in marriage and the family (qiwama and wilaya); ${ }^{88}$ for some, the press and public debates on khul in the Middle East essentially revolve around the challenge to male authority raised by the idea of women being able to exit the marriage without proving fault on the part of the husband. ${ }^{89}$ In the marital relationship, Kecia Ali establishes the husband's authority in classical fiqh as follows: "The husband's main right is to derive sexual enjoyment from his wife, and to that end he may exercise control over her mobility." "Compare this to Anderson's earlier presentation: "Broadly speaking, the marital relationship envisaged in the traditional law may be summed up in terms of a wife's duty to obey her husband in every lawful demand he may make - provided only that he has given her her 'prompt' dower - in consideration for his duty to provide her with suitable maintenance and support." "What Moors has termed the "gender contract" and Sonneveld the "maintenance-obedience relation" has been summed up by Tucker as "the marital bargain of nafaqa [maintenance] for absence of nushuz [disobedience]" which, together with guardianship, she finds to have been "constants in Islamic marriage", the great diversity in rules notwithstanding; despite the limitations on the husband's authority - upheld by the

\footnotetext{
${ }^{82}$ Abdal-Rehim 1996 106. See also Ivanova 1996 118-19.

${ }^{83}$ Tucker 2008 110; Rapaport 200574.

${ }^{84}$ Hinchcliffe 1968; Carroll 1996; Kamali 1984; Holden 2013.

${ }^{85}$ Arabi 2001 170-188.

${ }^{86}$ Bernard-Maugiron and Dupret 2008.

${ }^{87}$ Sonneveld 2012 .1. El Alami 2000135.

${ }^{88}$ Al-Sharmani (2013)

${ }^{89}$ Welchman (2007) 114.

${ }^{90}$ Kecia Ali (2008) 12.

${ }^{91}$ Anderson (1976) 114-15.
} 
jurists - "nushuz could not but be a defining concept for marital relations". 92 This does not contradict Cuno's finding that the application of the "legal formulation" of obedience rules "in real life varied according to the economic and social status of the household". 93

Cuno's particular consideration of the "curious case of the house of obedience" focuses on the changes in Egyptian procedural rules and court system in the nineteenth century, accompanied by the emerging "new family ideology" on the part of the elite in Egypt: he finds, like Sonbol before him, that the enforcement of this concept, in the sense of the court being empowered to return a 'disobedient' wife to her husband's house against her will, was an invention of the late nineteenth century. ${ }^{94}$ Their scholarship from court records establishes that prior to this, the sanction of the court was to hold the wife no longer entitled to maintenance from her husband, which is similar to the situation pertaining now in those MENA states that maintain the concept of 'obedience' in their laws. Cuno traces the coercive enforcement of 'obedience' orders in Egypt to France, via Algeria: "French colonial knowledge of Muslim family law was the likely vector of its transmission to Egypt."95 This scholarship explicitly challenges assumptions about what Cuno calls the "infamous legal regime" of the 'house of obedience' and pins it clearly on "legal modernization". 96

Scholarship carried out on the maintenance-obedience relationship in current or at least more recent practice includes examination of how the different claims of husband and wife are managed by courts and indeed - often strategically - by husbands, wives, families and wider communities. ${ }^{97}$ A feature of the scholarship discussed further below is the "growing disconnect" between the normative model of marriage with the husband as provider, and the implications this has for perceptions of law. But another area of academic as well as activist - focus in recent years has been special stipulations inserted in marriage contracts, which have the potential of modifying the effects that otherwise flow from the fact of the contract and notably of clarifying the circumstances in which a wife would not be held to be in a state of nushuz. Anderson deals with this issue briefly in his monograph on law reform, while El Alami mentions it only in passing (in discussing polygyny). ${ }^{98}$ Anderson's 1976 comment on practice (repeated from an earlier analysis of the then new Jordanian law of 1951) is illustrative of the way that attention to practice has changed in scholarship on MENA law: "I am told [...] that the insertion of such stipulations in marriage contracts is today the rule rather than the exception in upper class families in Jordan, and is becoming increasingly common in all classes." 99 Subsequent scholarship researched marriage contracts in court records in neighbouring Israel and Palestine with a view to ascertaining usage and scope. ${ }^{100}$ Similarly, later doctrinal scholarship devotes more time to stipulations in the

\footnotetext{
92 Tucker (2008) 82, 55. Moors 1995; Sonneveld 201217.

${ }^{93}$ Cuno (2015) 6; and see 215.

${ }^{94}$ Cuno (2015) 185-91; Sonbol (2008)115-16.

${ }^{95}$ Cuno (2015) 185.

${ }^{96}$ Cuno (2015) 15.

${ }^{97}$ Shehada 2008; Al-Sharmani 2013

${ }^{98}$ Anderson (1976) 114-117; El Alami (1992) 129.

${ }^{99}$ Anderson (1976) 116; see also Anderson (1951 JLFR) 192 n 4.

100 Layish (1975) 31-32; Welchman (2000) 163-82.
} 
marriage contract, ${ }^{101}$ and the 2008 edited volume on The Islamic Marriage Contract includes a number of articles specifically focussed on stipulations. ${ }^{102}$ Interestingly, two of the chapter authors indicate a change in position from their earlier (late 1990s) considerations of stipulations in the contract. ${ }^{103}$

But Anderson's 1976 comment on the motivation on the part of the legislators in expanding prospects for the enforcement of stipulations is perceptive: the intention was not only to provide relief in certain situations (that is, divorce) but to give wives "a measure of control over their own circumstances and those of their children."104 This comment provides context for historical scholarship that, from the 1990s, establishes that in certain places in past centuries, in the earliest Islamic centuries and indeed from pre-Islamic times, it was commonplace for the wife (or her guardian on her behalf) to insert conditions in the contract and that it was routine for courts to enforce them, in the sense of not holding her disobedient or in granting her a divorce should the circumstance stipulated against arise. ${ }^{105}$ Hanna has explained part of the significance of this scholarship in relation to the "Oriental Despot model, developed with regard to the state," which she argues "has often been applied to the family in the premodern period, either in explicit or implicit terms." ${ }^{\text {"106 }}$ Largueche's work on the "Kairouan marriage contract" (routinely stipulating monogamy) supports these efforts ("real history could be lived very differently to the ideals transmitted in doctrine"). ${ }^{107}$ Sonbol and Cuno argue that modernizing reforms to the Egyptian legal system in the $19^{\text {th }}$ and early $20^{\text {th }}$ centuries essentially closed the space previously accorded to negotiations on the shape of the contract and gave women considerably less control over the terms of their marriage than they had had pre-reform. Cuno uses this as well as associated reforms such as the 'Hanafization' of Egyptian legal practice in family law to dispute the "standard narrative" that family law remained untouched by legal reforms until the codes of the twentieth century. ${ }^{108}$ Sonbol in particular insists that women's (and indeed men's) insertion of stipulations should not be viewed in the first instance as having conditions of divorce secured, but rather as revealing, for specific historical contexts, "the expectations of a broad range of people" in regard to how their marriage would be lived, as well as illustrating women's agency in exerting a certain degree of control. ${ }^{109}$ Women largely stopped inserting stipulations in the newly issued marriage contract forms over the $20^{\text {th }}$ century, and even more recent research confirms that, in Egypt at least, judicial practice does not generally see stipulations as enforceable, with the exception of the delegation of talaq. ${ }^{110}$ Still, at the end of the twentieth century, the "New Marriage Contract" campaign in Egypt produced

\footnotetext{
101 Musa 1995, 252-263; Kecia Ali (2008) 21-27.

102 Quraishi and Vogel (eds) (2008); see in this volume Sonbol, Zomeno, Shah, Wynn, Zulficar.

${ }^{103}$ Wynn (2008) and 1996; Mir-Hosseini 2008 and 2007.

${ }^{104}$ Anderson (1976) 117.

105 Zomeno (2008); Sonbol (2008); Abdal-Rehim 1996 pp.98-103; Rapoport 2005 74-76; Cuno (2015) 132-37; Hanna 1996.

${ }^{106}$ Hanna (1996) 143.

${ }^{107}$ Largueche (2010) 3.

${ }^{108}$ See also Agmon (2006) 54-5 challenging the "accepted wisdom" that in Ottoman lands family law was not affected by $19^{\text {th }}$ century reforms.

109 Sonbol (2008) 96.

${ }^{110}$ Zulficar (2008)234-35; Sonbol (2008); Lindbekk (2014) 95.
} 
considerable scholarship from both observers and insiders: Zulficar, involved closely as the drafter of the document, notes in regard to the Egyptian women's movement that "we reclaimed our right to redefine our cultural heritage as Muslim women under the principles of shari ${ }^{\prime \prime} .111$

Zulficar's statement implicitly supports the more recent assertion by Sharafedin, who notes, in an article on Egyptian family law, that fiqh produced by the jurists was "sometimes different" from the practice of law in the shari a courts in history: "[ $\mathrm{t}$ ] his is why we may have two interrelated but different manifestations of "Islamic law.",112 In this, she follows Sonbol's earlier argument that, given the historical evidence of the disparities between figh manuals and court practice, "we should reconsider the idea that what fiqh has to say is synonymous with Shari`." "113 The state comes next, with its codifications of Islamic family law and integration of the court system, and the colonial and post-colonial retention of "shari " $"$ " jurisdiction, in one way or another, in Muslim family law matters led to the assertion that family law was indeed the "last bastion" or the "last stronghold" of the shari "a in many Muslim majority states: or, more accurately as Moors puts it, the "last stronghold of the shar ` $i$ establishment." 114 Cuno, following Messick, disputes that this was inevitable, arguing that "colonial-era scholars identified family law as the 'core' or the 'heart' of the shari 'a." 115 Tucker has wondered "[w] hether Islamic law retains any central identity or rather has devolved into fragmented sets of rules deployed for various purposes of politics and power." 116 And for his part, Dupret challenges scholars on the assumption "that personal status is, in Egypt and in many other Arab countries, the last stronghold of Islamic law."117 Dupret's challenge is methodological, disputing the way scholars frame their research into legal practice in Muslim majority states - in this work, personal status law in Egypt - arguing that "law is a practical accomplishment not an archaeological search for the Islamic pedigree of the norm." 118 All of which brings us to the second question: Who says what Islamic family law is?

\section{Who says so?}

It is certainly a commonplace to assert the diversity of Islamic family law, whether in relation to the differences within and between the traditional schools of law on different specific subjects, or in relation to practice in today's world of states, codified laws, courts applying them, and engaged citizens demanding change. Here, a useful distinction has been made between "discourses on the law" (public, political and religious debates) and

\footnotetext{
${ }^{111}$ Zulficar (2008)242. See also Noriani (2008).

${ }^{112}$ Sharafeldin (2015) 166.223.

${ }^{113}$ Sonbol (2008) 88.

${ }^{114}$ Moors (2003) 2. See Coulson (1969) 115-16.

${ }^{115}$ Cuno (2015) 159; Messick (1992)

${ }^{116}$ Tucker (2008).

${ }^{117}$ Dupret 2012 145; and see 2007 97; Dupret and Voorhoeve (2012) 2.

${ }^{118}$ Dupret (2007) 97
} 
"discourses of the law [...] (the practices of judges, lawyers and litigants)."119 Some of the most interesting recent historical scholarship looks at Islamic family law in practice with a view to hearing voices (judges, litigants) other than those heard through the fiqh literature and particularly the manuals of the schools. But it is with the advent of the state (colonial and post-colonial) that we really see what Tucker has referred to as an "epistemological break in the legal system" and the concerted questioning of who gets to say what Islamic family law is.

The codification of Islamic family law in the modern period constitutes "an alteration far more consequential than the move to a new framework of numbered articles might seem to indicate", including the passing of "a key dimension of interpretive authority" from individual jurists "to the collective bodies of national legislatures." ${ }^{120}$ Even if the state agrees that what it legislates is not the only valid expression of Islamic family law, its enforcement and recognition of certain rules and acts seek to construct 'the family' under Islamic law in particular forms. ${ }^{121}$ From the 1950s on, JND Anderson tracked the substance of details of the family law codifications in the Middle East and North Africa in detailed commentaries on the statutes and their origins in different fiqh sources, but without attempting to investigate their application himself. Anderson's scholarship is of its time, with a generally uncomplicated attitude to 'reform' and a positivist approach to 'law', legislation and the state. Noel Coulson published less specifically on family law (apart from inheritance) and did occasionally express reservations as to the application of Arab state codifications beyond the urban elite, referring to particular cases or trends in courts in different countries that had been reported to him. ${ }^{122}$ More broadly, however, in commenting on what he termed the "modern process of comparative law" employed by states to design family laws appropriate to their societies by drawing on the range of views available on different matters in figh, Coulson called this "a healthy process of social purpose" and noted that "[t]he status of women has been immeasurably improved." 123

The assumptions behind such statements by earlier scholars have been challenged since the mid-1990s by historians on a number of levels. Both Tucker and Sonbol question whether reforms of the late nineteenth and early $20^{\text {th }}$ centuries under the Ottomans and in Egypt were an unadulterated good for women in particular. ${ }^{124}$ Sonbol looks at cases before and after the Egyptian reforms and concludes they proved "a mixed bag for Egyptian women." 125 Tucker focuses on the range of opportunities in fiqh compared to the limitations imposed by the Ottoman Law of Family Rights (1917), and in her later book weighs the benefits of the substantive reforms as "offset by the loss of the leeway built into the

\footnotetext{
${ }^{119}$ Voorhoeve and Dupret (2012) 7.

${ }^{120}$ Masud, Messick and Powers (1996) 27

${ }^{121}$ See Cuno $(2015,1-2)$ and Sonbol $(2008,111,117-18)$ on the modern introduction of the Arabic terminology of al-usra for 'the family' and the accompanying focus on the nuclear family and the production of offspring as the object of marriage.

${ }^{122}$ Coulson (1969) 114.

${ }^{123}$ Coulson (1969) 39, 97.

${ }^{124}$ Tucker (1996); Sonbol (1998)

${ }^{125}$ Sonbol (1998) 285.
} 
traditional Islamic legal system."126 The comparison between the 'openness' of the premodern fiqh system and the 'closed' nature of the code (often expressed as flexibility versus rigidity) is emphasised by other scholars working with historical material. ${ }^{127}$ The way in which states selected particular fiqh rulings to construct their ideal-type Muslim family under their statutory interventions is described by Sonbol as a process of "state patriarchy", an interesting foil to Anderson's description of the "eclipse of the patriarchal family". ${ }^{128}$ The extent of the difference between Islamic family law and practice before the reforms and after, she says, merits the current manifestation being called "a new shari " $a$ ". ${ }^{129}$ The crystallization of this 'new' Islamic family law, under pressures of colonialism, imperialism and state formation, and later in the twentieth century of the growth of political Islam and what are seen as increasingly conservative visions of society and with it the family, is challenged in more recent scholarship.

Key to the idea of pre-codification flexibility is the way in which the courts operated in pre-modern times. Coulson asserted that the new way that Islamic family law was being applied by states gave greater room for the recognition of social exigencies: "traditionally the qadi was hidebound" by rigid procedural and evidentiary rules as well as by substantive legal rules in his school's manuals, "which left him little or no room for personal initiative", while the current situation sees states explicitly giving wider discretion to the courts in applying Islamic family law "so that they now assume, to a much greater extent than hitherto, the responsibility of organs of real social purpose." ${ }^{130}$ Historical scholarship on the workings of shari a courts in pre-modern and early modern times (in Egypt and under the Ottomans) has drawn a much more nuanced picture, with the court at different times and places being very much tied in to the community, serving a fundamental purpose as arbitrator and mediator in pursuit of what the qadi would then have considered "gender and social justice". ${ }^{131}$ In addition, as already noted, questions are raised as to the extent to which the traditional doctrine as set out in the fiqh texts reflected social (and court) practice. ${ }^{132}$ More recently still, as discussed further below, scholars discuss whether the script set for marital relations in codifications of Islamic family law across the Muslim world reflects the reality of marriage today in a variety of contexts: and if not, what the implications are. ${ }^{133}$

In a different kind of scholarship, from the 1970s, we see compilations (mostly translations by the authors) of different statutory interventions in different states. The first of these appears to have been Tahir Mahmood's extraordinary effort, ranging over multiple jurisdictions in the Middle East and North Africa, South and South East Asia and Africa (including in the final edition statutes of Islamic family law in non-Muslim majority states)

\footnotetext{
${ }^{126}$ Tucker (2008) 22.

${ }^{127}$ Messick (1992). Cuno (2015) 204.

${ }^{128}$ Anderson (1968); Sonbol (1998) 285.

${ }^{129}$ Sonbol (1998) 285.

${ }^{130}$ Coulson (1969) 107-08.

${ }^{131}$ Agmon (2006)45, 55-55, 128; Sonbol (ed) 1996. See also Semerdjian (2008), Peirce (2003).

132 Moors 1999. Messick (1992).

${ }^{133}$ Mir-Hosseini (2015, 17-18); Al-Sharmani (2013 45); Shehada (2009 44).
} 
and appending summaries of case law. ${ }^{134}$ Mahmood presented his work as "essentially descriptive" and explicitly denied any evaluative purpose in his analysis. ${ }^{135} \mathrm{He}$ also assumed a certain 'basic' familiarity with the principles of Islamic family law; this approach is not followed in subsequent compilations, with El Alami and Hinchcliffe in the 1990s presenting an introduction on 'the uncodified law' before embarking on the substance of their work, translations of "Islamic marriage and divorce laws" in the Arab states. ${ }^{136}$ Jamal Nasir, whose works include one text focusing on the Arab states and one including also South Asian material, aims his work primarily at practitioners in the non-Muslim West as well as Muslim communities in Western states; he includes an introduction to Islamic jurisprudence and proceeds through the different areas of Islamic family law setting out the positions according to the different schools followed by a presentation of how those issues are dealt with in the different states under consideration. ${ }^{137}$ Such 'manual' type publications ${ }^{138}$ refer mostly to primary and fiqh sources and do not refer to Western scholarship around the issues discussed, nor do they problematize the notion of "shari 'a" or "Islamic family law." They are vulnerable to being quickly overtaken by the promulgation of new or modified statutes, of course, necessitating revisions and updates; and more recently the change in accessibility of statutes notably through electronic resources (let alone, as yet, the imminent transformation of on-line translation capabilities for the individual practitioner or researcher).

In a sense what the last two examples of source books are doing is setting out what contemporary states have presented as Islamic family law in their codes compared with what the traditional jurists expounded as doctrine on the individual issues. Other types of scholarship have also to a certain extent tracked the codes, but with a focus on time and place-specific application in the courts. The first such effort appears to have been Layish's research into shari 'a court practice with Palestinian Muslims from the establishment of the state of Israel to the late 1960s. This informative 1975 study can be situated in its time: it is intended among others for "the Orientalist" and explores how "the sharia has reacted" in light of the fact that "[t]he traditional equilibrium between the shari ' $a$ and Muslim society has been irrevocably upset, not by change from within, but as a result of direct contact with a modern Western society." 139 Subsequent studies provide the basis for the finding, in the $21^{\text {st }}$ century, that a "distinctive feature of recent scholarship" is the focus on local practice, away from "an idealized model of Islamic law to its manifold instantiations in specific times and places." ${ }^{140}$ While some of these focus on court practice as read from the court records, including considering the practical implementation through the courts of the state

\footnotetext{
${ }^{134}$ Mahmood (1972, 1987, 1995).

135 Mahmood (1972) Preface, reproduced 1995 p.iii.

${ }^{136}$ El Alami and Hinchcliffe $(1996,1998)$.

${ }^{137}$ Nasir 1986, 1990, 2001 (2009); 1990, 1994, 2009. See also El Alami (1992).

${ }^{138}$ See Nasir (1990) 5.

${ }^{139}$ Layish (1975) x

140 Masud, Peters and Powers 20124.
} 
codifications, ${ }^{141}$ others draw also on anthropological approaches to engage the material as observed in particular frames that do not take the 'law' as the starting point. ${ }^{142}$

The processes of family law reform that began in what I have termed the "third phase" of Muslim family law reform in MENA has generated scholarship that shows the changed nature of interest in Muslim family law. Women's rights are a foregrounded issue, along with the advocacy positions of women's rights organisations in the national debates and also often involving international and diasporic women's rights organisations, and gender as an analytical framework. A collection of these "discourses on the law" were published in 2003 as a themed issue of Islamic Law and Society looking at public debates in these processes, ${ }^{143}$ and another set were included in a 2009 edited collection, notably including Cole's exposition of the process in transitional Iraq. ${ }^{144}$ The Egyptian law of 2000 (legislating for judicial $\mathrm{khul}^{\text {) }}$ has also given rise to a substantial scholarship, focusing on the text, the state's textual justification of it, parliamentary and other debates. ${ }^{145}$ Sonneveld's recent monograph combines an analysis of the texts, court practice and out-of-court narratives with an examination of the public debate inter alia through the medium of films and cartoons. ${ }^{146}$ Above all, the 2004 Family Code in Morocco gave rise to a veritable deluge of commentaries and analyses, some considerably better than others. The volume of scholarship can be at least partly attributed to the invocation of international human rights discourse (particular the equality principle) in the debates and indeed in the law, and the engagement of the Moroccan authorities with the international human rights system. The availability of unofficial English translations of the law on-line quickly after its promulgation not only indicates interest from international women's rights activists but also facilitated the production of articles on this law The best scholarship on the substance of this law goes beyond 'assessments' of the text and its equality provision to include reflection on court practice with a view to future amendments to the law. ${ }^{147}$ In line with recent scholarly interest in family law regulation among Muslim communities in the West, Foblets considers the implications of the new law for Moroccans living in Europe. ${ }^{148}$

Away from court implementation of the codes, the influential study of the first codes of Algeria, Morocco and Tunisia by Charrad, a comparative-historical sociologist, investigates the political circumstances of the adoption of the three laws with a view to situating how the different postcolonial states dealt with women's rights in their post-colonial family laws in light of "the relationship between state and tribe." 149 Tucker has since partly disputed Charrad's findings on the relative lack of impact of women's rights activism on the content of the codes, while other scholarship has also focused on the mutual and dynamic relationship between state formation (and development) and Islamic family law substance

\footnotetext{
${ }^{141}$ Welchman 2000, Shaham 1997.

142 Rosen 1989, 2000; Mir-Hosseini 1993; Hirsch 1996; Moors 1995;

${ }^{143}$ Moors, Buskens, Schultz, Welchman and Wurth 2003.

${ }^{144}$ Cole, Welchman, Salime 2009. See also Abu-Odeh (2004).

${ }^{145}$ Arabi 2001; Bernard-Maugiron 2008.

${ }^{146}$ Sonneveld 2012.

147 El Hajjami 2013; Carlisle (2013); Rosen (2008).

${ }^{148}$ Foblets 2008.

${ }^{149}$ Charrad 2001 9. See also Jasso (2014).
} 
and processes, with citizenship becoming a key frame. ${ }^{150}$ Another angle from the 1990 s was Mayer's 1995 suggestion that the spousal relationship in North African family law codifications might have more to do with 'Mediterranean' than with Islamic law. Mayer's examination poses the prospect of higher courts taking positions such as that in Turkey on issues previously included in statutory law (in this case, the wife's need for her husband's consent to her work outside the home). But the scholarship on significant decisions on Islamic family law by higher courts in Arab countries is mostly concerned with Egypt's Supreme Constitutional Court. ${ }^{151}$ This scholarship, in so far as it deals with family law, is less focussed on the substance of family law than on the way the Court handles the matter of its own interpretative authority - that is, in the Court saying what Islamic family law is. This scholarship considers how the Court approaches the authority of the fiqh texts, Egyptian statutory law (being challenged by the petitioner) and the Court's own mandate in deciding whether or not a particular statutory intervention in family law was contrary to the principles of the shari 'a. Looking at a 1996 decision on post-divorce maintenance and a 2002 ruling on the constitutionality of the law on khul, Johansen tells us that "[ $\mathrm{t}] \mathrm{he}$ authors who are empowered to rethink and reformulate Islamic law and Islamic normativity are clearly identified by the SCC: the legislature, political authorities, expert jurists and, of course, the judges of the SCC." The Court, he tell us, "relates norm production directly to political authority." ${ }^{\prime 152}$ Classical fiqh norms - in our case, on family law issues - no longer bind the Court or indeed the legislature. ${ }^{153}$

In South Asia, English-language scholarship, starting under British colonial rule, focussed primarily on jurisprudence from the courts, first under British control with eventual authority to the Privy Council in London, and subsequently under independent states. Under colonial rule, principles of English law were invoked in the interpretation of the Hanafi manuals available to judges, and the common law system gave precedent a status not familiar in civil law systems (nor yet in the traditional Islamic law system), thus lending added authority to the courts' findings of what Islamic law is. There is a voluminous literature examining "Anglo-Muhammad Law" or Muhammad Law, a term for which Fyzee offers an apology: "this ugly term as well as its variants [...] are all open to serious objection." 154 Much of this literature concerns family law, with in depth analysis and detailed examination of leading cases, and various authors have discussed the substantive impact of colonial-era scholarship and jurisprudence on Islamic family law. Michael Anderson however suggests in a 1990 collection that "it would be a mistake to ascribe too much importance to the effects of colonial law", noting that "indigenous processes" of scholarly study were also at work, with a resulting increase on "a scripturalist approach to the shari ' $a$ " in the late $19^{\text {th }}$ and early $20^{\text {th }}$ centuries. ${ }^{155}$ Post-independence textbooks on Islamic family law in South Asia, besides Fyzee's work on India, include a large 1998 textbook by Pearl and Menski, updating previous

\footnotetext{
${ }^{150}$ Tucker 2008 115; Sevgin (2013); Maktabi (2013).

${ }^{151}$ Although see also Mitchell (1997) and Voorhoeve (2014).

152 Johansen 2012 192-93. See also Bernard-Maugiron 2008.

153 Johansen 2012 191. See also Arabi (2001) 169-188 and Bernard-Maugiron 2008.

${ }^{154}$ Fyzee 1974 1-2.

${ }^{155}$ Anderson M., (1990) 220.
} 
works by Pearl. The joint-authored text, which as Hirsch notes is not without its critics, ${ }^{156}$ examines Islamic family law in India, Pakistan and Bangladesh but also includes separate and systematic consideration of how the English courts have dealt with what the authors term agrezi shariat. $^{157}$

The British colonial authorities issued certain piecemeal legislation particular to Muslim family law during their rule in India, some still in force, with amendments, in Pakistan and Bangladesh as well as India. And judges in the highest courts in British colonial rule in India set precedents in case law on substantive issues of Muslim family law. In Britain itself however, as cases began to come to court involving migrants from South Asia and British Muslims particularly of South Asian origin, the state's principle of a unified family law for all citizens allowed no such particularized statutory intervention. Over the last half century, and increasingly in common with other Western European and North American states, the courts have dealt with different claims, including those involving foreign law - the family laws of Muslim majority states - in issues of private international law (or conflict of laws), but also including claims between Muslim citizens. Scholarship on the treatment of dower in European and North American courts has been noted above, but there are also issues about the recognition of marriage and divorce processes: that is, legislatures are asked to rule not whether a marriage or divorce is "Islamic" but rather whether it is a marriage or divorce under their domestic law. In the $21^{\text {st }}$ century, scholarship has tracked these developments not only in regard to case law ${ }^{158}$ but, increasingly, in regard to Muslim community-based mechanisms and their role in family law regulation in Western states. Some of this can be squarely placed in Hirsch's consideration of post-9/11 anxieties on the part of states and majority communities; the sub-title of Berger's 2013 timely collection ("facts, fears and the future of Islamic rules on family relations in the West") points to this context of "moral panic" $" 159$ and includes case studies from across Europe, North America and Australia. Another recent collection focussing on "divorce in Islam" likewise includes a number of contributions from non-Muslim majority jurisdictions in Europe but also in South Africa, and includes similar references to anxiety on the part of non-Muslim states. ${ }^{160}$ And another, Managing Family Justice in Diverse Societies, while not specific to Islamic family law, contains considerations of it in the UK, Iran, Bangladesh and South Africa, with something of a shared theme of legal pluralism and the standing of constitutional norms, for example of gender equality. ${ }^{161}$ The essays collected in Jeppie et al 's excellent (2010) volume, on Muslim Family Law in Sub-Saharan Africa, are attentive to constitutional dynamics in post-colonial states as well as to the 'colonization' of Islamic family law under British and French colonial regimes. ${ }^{162}$

\footnotetext{
${ }^{156}$ Hirsch (2006) 176.

${ }^{157}$ Pearl and Menski (1998) 58.

${ }^{158}$ Foblets (2007); Fournier et al (2012); see Arshad 2010 for a handbook for UK practitioners.

${ }^{159}$ See Turner and Richardson (2013) 55; Razack (2008) 92;

${ }^{160}$ Mehdi, Menski and Nielsen (eds) 2012.

${ }_{161}$ Maclean and Eekelaar eds (2013), in which see Bano, Ghanea, Chowdhury and Amin.

162 Jeppie, Moosa and Roberts (2010): see especially the Introduction and chapters by Allie, Moosa, Hirsch, Lydon.
} 
In the UK, initial proposals for a separate Muslim family law system came in the 1970s; the first two Shari $a$ Councils were set up in the 1980s and Nielsen (who was involved in a contemporary cross-country study) observes that the issue for many Muslims is the legitimacy of the judicial authority - "it is the authority under which a judicial process functions, rather than the substance of the law itself which becomes a key consideration". That is, it is not so much a question of "what is Islamic family law" as of "who says so"? More broadly Nielsen suggests that it "could be argued that the tensions regarding the wish for some form of shari 'a family law principles to apply among Muslims living in Europe are - yet another - consequence of Europe's past imperial adventures." ${ }^{163}$ The tensions to which Nielsen and others refer increased considerably in different contexts in the post 9/11 world. A burst of scholarship followed the public debates and government action following the announcement by a Muslim organisation in Canada "that it was setting up a 'shari 'a court' in Ontario under the auspices of the Arbitration Act". ${ }^{164}$ The authors detail the debates, the law and potential legal ramifications of the proposal and the subsequent exclusion of binding faith-based arbitration on family law matters; human rights obligations and Constitutional guarantees are evoked and the frame of citizenship is a focus, while the persistence of Muslim family law practice is also noted - "shari a and talaq are alive and well". ${ }^{165}$ A piece by Marion Boyd, a previous Attorney-General who was charged by the authorities with providing recommendations for ways forward, details the interventions by those who were in opposition and gives a sense of the painful nature of some of the debates. ${ }^{166}$ Sherene Razack provides an insightful and reflective analysis from a panel of Muslim feminists and the contradictions they found themselves facing: Muslims were presented as "pre-modern" in the debates and it is, she writes, "often through the language of human rights and gender equality that empire is accomplished today." 167

Boyd's piece is included in a volume published a few years after a second major public controversy on Muslim family law in the West. This was the 2008 intervention, in a high profile practitioner-academic lecture series on "Islam and English law", by the then Archbishop of Canterbury, Rowan Williams. Williams proposed a "transformative accommodation" and was reported as referring to the "unavoidable adoption of shari 'a law". ${ }^{168}$ The "media storm" that ensued was followed, in due academic time, by scholarship that included a 2013 volume edited by the original convenor of the lecture series and including a particular focus on legal pluralism, particularly in relation to Muslim family law in the UK. ${ }^{169}$ In this context, some scholars argue for greater recognition by state law and courts of Muslim marriage and divorce practice with a more pluralist approach to law; ${ }^{170}$ others are more cautionary; ${ }^{171}$ and others concentrate on the implications, mostly for women,

\footnotetext{
${ }^{163}$ Nielsen (2013) 90, 94. Compare Poulter (1990).

${ }^{164}$ Boyd (2013) 177-78.

${ }^{165}$ Fournier, Setrakian and McDougall (2012) 237. See Bakht (2004), (2006); and Islam.

${ }^{166}$ Boyd (2013)

${ }^{167}$ Razack 200886.

${ }^{168}$ Williams (2013) (2008); Griffiths-Jones (2013).

${ }^{169}$ Griffiths-Jones (2013).

${ }^{170}$ Shah (2013); Pearl and Menski (1998) 77-80 and 170-175.

${ }^{171}$ Ali (2013)
} 
of reliance on these non-state processes, particularly in regard to securing a divorce under Islamic law alongside a civil divorce - the so-called 'limping marriage' where a marriage is held extant in one legal system but not in another or where a wife has obtained a civil divorce but is unable to obtain a religiously-recognised divorce from her Muslim husband ${ }^{172}$ The frames of multiculturalism and citizenship and the paradoxes posed by attention to both individual and community rights are central to scholarship on mechanisms for Muslim family law regulation. ${ }^{173}$ Scholars also investigate the motivations of those Muslims in the West who engage in "Islamic marriages" without reference to registration (and therefore 'recognition') processes. In the Netherlands, Moors finds that unregistered marriage among Muslims provokes anxiety on the part of the state about this being "an indication and instrument of radicalization and an attempt to develop a parallel society based on the shari 'a." ${ }^{174}$ That is, the anxiety is provoked not by the fact that the couple are not concluding a civil marriage, but rather by the fact of it being an "Islamic" marriage. Moors found no evidence that ideology was producing a refusal of state procedures and registration on the part of young women involved in such marriages but rather a wide variety of reasons for concluding (first, at least) an Islamic marriage. On the other hand, in the mid 2000s, scholarly effort in the UK went into a collaborative community-based effort to draft model Muslim marriage contracts presented as compliant with law in the UK, ${ }^{175}$ while in the US scholars reported a growing interest in the Muslim population in drafting more "personalized" Muslim marriage contracts - documents that are "not a generic stamp of mere legal status conferred by some external authority, but rather, full, detailed expressions of the way each couple defines itself."176

At the same time, a deliberate lack of engagement with state registration procedures and requirements for marriage and divorce is also documented in Muslim majority states, sometimes presented as the normative pull of shari $a$ in a contested socio-political environment. A considerable amount of scholarship has focussed on the legal and social motivations and implications of marriages (notably lack of judicial remedy) conducted outside the state system in different Arab states, and the reactions of the public and the judiciary to the statutes, particularly in Egypt but also in Morocco and more recently in Syria and the UAE. ${ }^{177}$ In Indonesia, Bedner and Van Huis argue pragmatically against proposals that the state enforce more strictly its existing rules on marriage and divorce registration. ${ }^{178}$ In regard to 'unofficial' (unregistered) marriages in the Middle East and North Africa, public disquiet appears to have centred not so much around people marrying without the knowledge of the state, but at young family members (mostly females) marrying without the knowledge of their families. Hasso considers these "secret marriages" in Egypt and the UAE as "marital innovations" and notes that "customary relationships in the contemporary period are often interchangeably referred to as 'secret' marriages to stress their perceived violation of

\footnotetext{
172 Bano (2012), Rutten (2013) 102-104. Liversage (2013).

173 Bano 2013; Boyd (2013); Shah 2013; Foblets (2008).

${ }^{174}$ Moors (2013) 159.

${ }^{175}$ See Muslim Marriage Contract (2008); for an earlier effort see Carroll and Kapoor (1996) 176-77.

${ }^{176}$ Quraishi and Syeed-Miller (2004) 191.

177 Shaham 1995, Mir-Hosseini 1993, Carlisle 2008; Hasso (2011).

${ }^{178}$ Bedner and Van Huis (2010).
} 
'shari ' $a$ ' and state law." 179 Her analysis of these marriages focuses on what the motivations are and how the courts deal with them when they are brought to their attention, often in cases where there is a child and the husband has disappeared or is denying the marriage, obstructing access to a birth certificate and therefore to other public resources. ${ }^{180}$ Hasso goes on to consider "misyar" or "ambulant" marriage as "secret polygyny". ${ }^{181}$ Arabi had earlier considered in the context of 1990s Saudi Arabia the arguments for and against this type of marriage, where the wife agrees at the time of the contract to waive her rights to the husband providing a marital home and to maintenance, and where the secrecy paradigmatically involves keeping the marriage secret from an existing wife; his treatment is in the framework of the way in which people's practice created pressure on Saudi authorities to recognise (albeit in restricted fashion) this institution, an example of what he calls "grass roots lawmaking”. 182

Carlisle's observation-based analysis of a Damascene court's consideration of a claimed out-of-court marriage focusses on the efforts by the Syrian judge to establish whether, according to the witnesses, "the events resulted in a valid marriage", and to this purpose investigating social practices as a part of his assessment. ${ }^{183}$ The scholarly interest in "Islamic family law" as understood by judges (as well as jurists) and by lay people is a feature of the more recent scholarship. ${ }^{184}$ We have already seen how historians have challenged previous accounts of Islamic family law by reviewing court records and other sources. This work also applies to more recent historical periods and indeed current times. Perhaps one of the most vivid debates on how to read court records comes in the disagreement between Islamic law historian Aharon Layish and anthropologist John Davis, published in the 1998 introduction to a collection of mid-20 $0^{\text {th }}$ century Libyan Shari a court records, over half of which concern family law. Davis had collected the facsimiles of the records during extensive field work and subsequently made them available to Layish. In his introduction, Layish insists inter alia that "the historian of Islamic law makes a clear distinction between shari ' $a$ and tribal custom." ${ }^{185}$ Davis disputes Layish's notion of a "process of sedentarization", arguing that "modern scholarship" contests "label-driven accounts" (such as nomads being ruled by custom and settled peoples by law).

"Anthropologists and legal historians come to study law in different ways", he tells us, and the events that bring people to court are linked to different contextual elements that may be inferred from the "event-droppings" provided by documents. "That is quite different from an explanation in terms of a disembodied 'process' - of Islamisation, or civilisation - involving a struggle between two bodies of law assumed to be coherent, monolithic and incompatible." ${ }^{186}$ In a 2005 reflection covering the English translation of the same documents, Layish concedes that it is "anthropologically significant" if the Bedouin in the

\footnotetext{
${ }^{179}$ Hasso (2011) pp.81-82.

${ }^{180}$ Ibid 80-88.

181 Ibid 88-92. See also Yamani (2008) 106-111.

${ }^{182}$ Arabi 2001, 147-167.

${ }^{183}$ Carlisle 2008.

${ }^{184}$ See Tucker (2008) 19.

${ }^{185}$ Layish (1998) 6.

${ }^{186}$ Davis (1998) 10-13.
} 
records "identify their day-to-day legal practice indiscriminately with the shari 'a", but insists that "the historian of Islamic law cannot simply accept this assumption. A clear distinction exists between orthodox shari 'a and tribal customary law, and when the Bedouin are following custom, the scholar must point this out." 187 Who says what Islamic law is?

It is certainly the case that much $21^{\text {st }}$ century scholarship on Islamic family law unsettles the more orthodox narratives of both 'what is Islamic family law' and 'who says so'. There is considerable work on contemporary court practice, often with insights drawn from court observation, following the routine procedural focus of judges in adjudication and mediation, the work of court-appointed arbiters, litigants and their perception and conduct. ${ }^{188}$ Some of this maps the discourses and procedures followed by the actors studied in order to discern, for example for Stiles, a cultural anthropologist, "when are certain cultural practices understood as 'properly Islamic' or 'religious' and by whom?" 189 Or, in the case of Guinchi, introducing her court practice-focussed collection, the "religiously-inspired judicial activism" of judges. ${ }^{190}$ In 2006, Masud, Peters and Powers suggested that "in future scholars may want to focus greater attention on the work of the qadi and the process of judicial decisionmaking." "191 That same volume contained an article by Baudouin Dupret that has had significant influence on subsequent studies. Using an Egyptian family law case to illustrate his argument, Dupret states that

[t]here is no reason to assume that what people refer to as Islamic law is identical to a set of technical provisions that form the idealized model of Islamic law. Nor is there any reason to assume the contrary. To a certain extent, the question is not relevant. [...]To the question, What is Islamic law? we should substitute the question, What do people do when referring to Islamic law? ${ }^{192}$

His point is that by focussing on an assumed framework, research misses its aim. A later piece co-authored with Maaike Voorhoeve critiques the tendency, in scholarship on the legal systems of MENA, "to ascribe overarching importance to Islam in the inception and organisation of the law". ${ }^{193}$ In this regard they very appositely remind us that family law is but one small part of the legal systems of MENA countries. They advocate "paying attention to practice as the only area where the law is seen to be at work" and that scholars must consider how Islam is invoked and referred to: "thus, 'Islamic law' corresponds to what people consider as specifically Islamic in the law, independent of any consideration about the truth of such a claim." ${ }^{194}$ The articles in this collection illustrate this approach. ${ }^{195}$ Following Dupret in 2014, Voorhoeve applies an "ethno-methodological study of behaviour" to take the

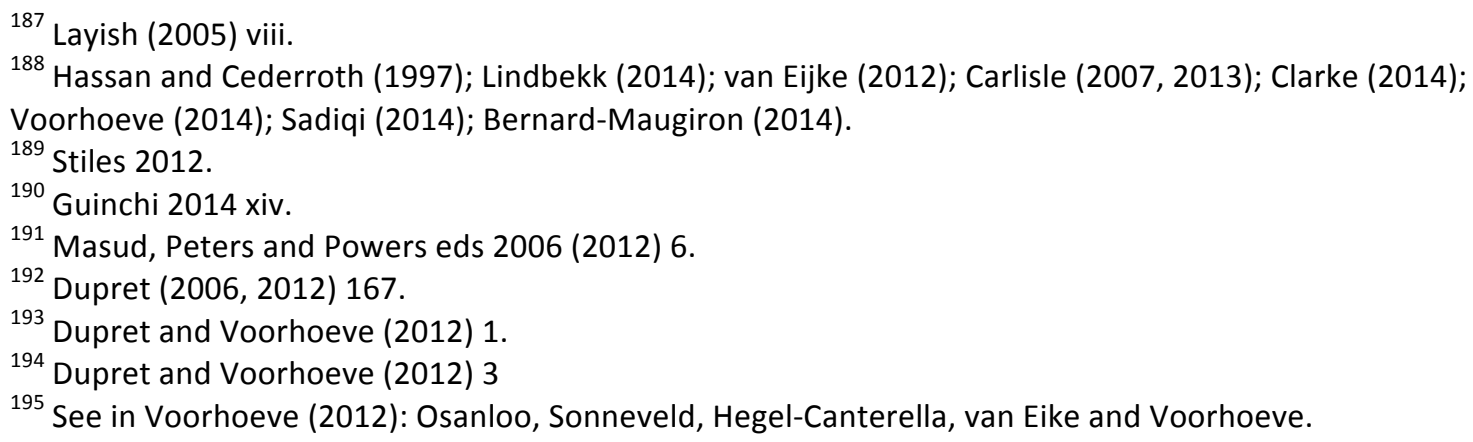


statements of actors about their own behaviour at face value in her study of family law practice at a Tunisian court and speaks of a "new wave" of scholarship in this vein, with scholars who acknowledge that their data is "messy" and do not assume apriori structural frames through which to view it. ${ }^{196}$

Thus, with no straightforward answers to the question "what is Islamic family law?" nor yet "who says so?" we move, relatively straightforwardly, to the question "Islamic Family Law: So what?"

\section{So What?}

In a situation where the authority of apparently agreed-upon substance, and the authority to pronounce thereon, are increasingly unsettled, a growing body of scholarship engages with what Islamic family law could/should/might be. Two recent and significant contributions in this regard are the collections edited by Mir-Hosseini with different colleagues in 2013 and 2015. ${ }^{197}$ The nature of the scholarship, and the processes that gave rise to the publications, are as significant as the content. The volumes engage with Muslim Family Law (2013) and Muslim Legal Tradition (2015) and both focus particularly on male authority in the family (guardianship - wilaya and qiwama), notions of gender equality and the "lived realities" or "social reality" of Muslim women in order to explore family law issues. The first collection was facilitated by the "Oslo Coalition on Freedom of Religion or Belief"; those involved are at pains to emphasise that "this was not an inter-religious dialogue, but a Muslim project, bringing together Muslim experts" from different disciplines and professions. ${ }^{198}$ The 2015 collection is the first output of the Knowledge Building Initiative of Musawah (the Global Network for Justice and Equality in the Muslim Family), which was launched in 2009 in Kuala Lumpur. ${ }^{199}$ Both are examples of engaged scholarship: an explicit aim is the "reform" of Muslim legal tradition and in particular that related to family law, as a basis for the reform of Muslim family law and relations. They include textual, philosophical and jurisprudential reinterpretations and exegetical analyses ${ }^{200}$ as well as situation-specific explorations of reform processes. ${ }^{201}$ Women's and human rights are invoked as well as gender equality and feminist method and engagement. ${ }^{202}$ The 2015 book wants to "develop feminist knowledge that is grounded in Muslim tradition while engaging critically with it." 203 The distinctive features of this scholarship include its emergence from collaborative processes, not only among but between scholars, scholar-activists and activists. Not all scholars have welcomed this work; anthropologist Lila Abu-Lughod, in a critique of

\footnotetext{
${ }^{196}$ Voorhoeve (2014) 9, 18. She references the work of Dupret, Carlisle and Shehada.

${ }^{197}$ Mir-Hosseini, Vogt, Larsen and Moe eds (2013); Mir-Hosseini, Al-Sharmani and Rumminger eds (2015).

${ }^{198}$ Mir-Hosseini et al eds Introduction (20i3) 2.

${ }^{199}$ See Anwar (2013) 115,(2008); Mir-Hosseini (2012). Musawah's publications are available on-line.

200 Masud (2013), Abu-Zayd (2013), Abdul Kodir (2013), Eshkevari (2013), Kadivar (2013) and Emon (2013); MirHosseini (2015), Abou-Bakr (2015), Lamrabet (2015), Chaudhry (2015) Wadud (2015).

${ }^{201}$ Al-Sharmani (2013), Sharafeldin (2013), El Hajjami (2013), Anwar (2013); Sharafeldin (2015), Welchman (2015), Larsen (2015).

202 Sharafeldine (2013, 2015), Al-Sharmani and Rumminger (2015).

${ }^{203}$ Mir-Hosseini et al eds (Introduction 2015) 4.
} 
Musawah, is uneasy about "the new consensus in the international rights community and among many Muslim feminist activists and scholars that Islam and women's human rights must be reconciled and that internal reform is necessary."204 There is also disquiet at the use of Muslim family law as a trope for constructing the (less than 'civilised') nature of Muslim men in the context of the imperial adventures of Western powers particularly since 9/11 and the complex alliances - or at least resonances - between these military and other exercises and certain feminist discourses in the West. ${ }^{205}$

Muslim feminist scholarly approaches to jurisprudence and equality arguments have been established since the 1990s, ${ }^{206}$ but Zainah Anwar (a founder and former director of Sisters in Islam in Malaysia and a co-founder of Musawah) records increasing interest on the part of activists in exploring Islamic sources after the turn of the century. ${ }^{207}$ The 1990 s saw examples of engaged scholarship involving broader networks and not involved in seeking to re-work Islamic jurisprudence - notably, Women Living Under Muslim Laws (WLUML), under whose auspices two valuable collections were published in 1996, both edited by established scholars. Thus in WLUML's first 'Special dossier' Hoodfar as editor refers to women "galvanizing for change" in different societies around the world and situates the publication as a contribution to these efforts by examining some of the strategies being used in different contexts. ${ }^{208}$ The second publication was an "Information Kit" on delegated talaq ("the Muslim woman's contractual access to divorce") and pertains particularly to South Asia, with a range of documents including the forms of different marriage contracts as well as academic essays and practical advice on how to draft a marriage contract containing an effective delegation of talaq to the wife. ${ }^{209}$ WLUML went on to produce several versions of an ambitious "action-research" resource book, Knowing Our Rights, looking across different Muslim communities and evaluating existing family law provisions and structure with a view to assessing the most "option-giving" for the greatest number of women affected by them (at the current historical moment." ${ }^{210}$ North African scholars compiled the Guide To Equality in the Family in the Maghreb that in turn is cited as an inspiration for Musawah's work. ${ }^{211}$ Another 'global resource book', edited by Abdullahi An-Na'im, began life as an on-line project out of Emory University that subsequently produced two collections of materials aimed at "serving as a resource for internal initiatives aimed at expanding and protecting women's rights in the family as articulated in human rights norms." 212 An-Na 'im insists on the "futility of adopting a reductive approach to the study of Shari a-based family law" and that while the material presented in his collection will indeed serve as a "resource book", it is intended "also to encourage a more candid and thorough examination of the underlying issues." His own position, set out in greater detail in his later publications, is "admittedly

\footnotetext{
${ }^{204}$ Abu-Lughod (2013) 185.

${ }^{205}$ See also Kapur (2012) on the right to gender equality; and Hirsch (2006).

${ }^{206}$ See al-Hibri (1997).

${ }^{207}$ Anwar (2013); Emon (2013) 237.

${ }^{208}$ Hoodfar (1996) 4. See in this collection especially WRAG (1996).

${ }^{209}$ Carroll and Kapoor (1996).

${ }^{210}$ WLUML (2003) 21. The last version (2006) is available on-line.

${ }^{211}$ Collectif 95 Maghreb-Egalité (2005); Anwar (2013) 116.

${ }^{212}$ See Welchman (2004) 1 ; this is the companion volume to An-Na 'im (2002).
} 
controversial" as he calls for "a clear and categorical acknowledgement of the fact that family law in Islamic countries today is not, and indeed cannot and should not be, founded on Sharia."213

Thus since the 1990s we have activists working with scholars, and scholars identifying as 'scholar-activists', with manuals and 'toolkits' and more recently still websites and different forms of communication and dissemination that are used to elicit and spread ideas about the workings of Muslim family law in different contexts, strategies for making the greatest use of the law for the best protection of different areas of women's rights in the family, and the prospects for reform of the law and strategies to achieve it. Interestingly, Tucker links this kind of advocacy to previous centuries of women 'waging law' by demanding their rights at court. ${ }^{214}$ While noting considerable opposition to this work and the groups carrying it out, Tucker considers that "these are the people and groups to watch in the near future, in light of both their energy and commitment." 215

Tucker's book also illustrates the extent to which human rights law and norms are now invoked or implicated in Islamic family law scholarship as well as advocacy. ${ }^{216}$ Besides examining the advocacy campaigns, scholars may compare human rights norms (particularly the equality and non-discrimination norms) with institutions of Muslim family law and/or practice in particular post-colonial states, or consider similar issues arising in non-Muslim majority states in regard to their minority Muslim populations and proposals for a degree of legal pluralism. ${ }^{217}$ And international human rights organisations also now publish lengthy reports on matters of Muslim family law and practice in particular Muslim states. ${ }^{218}$

We also see scholarship mapping and analysing family law reform processes from a range of angles. Some look at state procedures and processes and responses to civil society demands $;{ }^{219}$ some focus on women's activism, feminist activism and women's movements and indeed individual participants therein - and how and in what circumstances their discourses and demands change; ${ }^{220}$ some start from a focus on citizenship to examine processes of Muslim family law reform or use family law as a lens through which to examine other subjects, such as feminism. ${ }^{221}$ In much of such scholarship, "the law" and its discourses certainly lose ground to discourses "on" the law; often the issue of it being "Islamic" or "Muslim" family law is treated entirely matter-of-factly, almost incidentally. This appears entirely inevitable. If there is no longer a familiar body of jurisprudence from a recognised source of authority who may expound and indeed expand it, then others, from non-orthodox academic or disciplinary backgrounds may join the debate; and the debate may become not

\footnotetext{
${ }^{213}$ An-Na im (2002) 20.

${ }^{214}$ Tucker (2008) 223-24; and see 124.

${ }^{215}$ Tucker (2008) 225.

${ }^{216}$ Tucker (2008) 80-81.

217 See for example Rehman (2007); Mir-Hosseini (2012); Ali (2000); Amin (2013); Foblets (2013); Weiss (2009).

${ }^{218}$ Human Rights Watch $(2004,2011,2015)$. For a critique of this approach see Modirzadeh (2006).

${ }^{219}$ Cole (2009); Welchman (2009); Chowdhury (2013); Fawzi (2004).

${ }^{220}$ Anwar (2008, 2013); Dahlgren (2012, 2013); Noriani (2008); Salime (2009); Sharafeldin (2015) Shehada

(2013); al-Sharmani (2013); Osanloo (2013); Nazneen (2013).

${ }^{221}$ Maktabi (2013); di Ricco (2012); Sadiqi (2008).
} 
so much about what the law is (normatively and descriptively) but what it could and perhaps should be. See for example the explicit attention given to "alternative forms and sources of knowledge" in Musawah's compilation of women's life stories as a way to understand the 'meaning' of male guardianship and authority. ${ }^{222}$ This research is carried out precisely to understand how this framing of the family works in daily realities, or rather whether it does: in these stories, as is noted in many other context-specific examinations, the maintenance part of the formula is failing as man are unwilling or unable to provide for their families. ${ }^{223}$ There is a "disconnect" between the gendered roles and rights in the family recognised and endorsed by state law invoking fiqh authority and the realities of economic and social pressures on the family in different parts of the Muslim world. ${ }^{224}$

Another type of scholarship that may uncover such tensions administers and analyses the results of opinion polls asking respondents about family law and revealing significant insights about what people think about the law and what they expect it to do. ${ }^{225}$ In Palestine, polls have shown a strong emphasis on context - so for example revealing support among both men and women for divorced women to have some degree of access to assets acquired during the course of her marriage with her former husband. Hammami and Johnson consider this finding to be a result of "changes in the traditional male breadwinner/economically dependent wife model" and an increasing recognition of the wife's contribution to building marital assets, as well as her economic vulnerability in the case of the termination of her marriage. $^{226}$

\section{Concluding Remarks}

Such analyses clearly have meaning for the complex relationships of different Muslim constituencies with their perceptions of Muslim family law, perhaps in particular how different sectors and communities expect the law to produce justice, in their place and time, at least as much as where they expect to find its inspiration or its origin. More generally, English-language scholarship on Islamic (or Muslim family) law is expanding exponentially, within as well as beyond the disciplines with which it was traditionally associated. The state is no longer regarded uncritically, and approaches to Islamic family law have become among other things - one lens among others through which to explore a number of different political and social relationships. A substantial scholarship continues to explore court practice in specific contexts, and to investigate the wider implications of particular concepts within Islamic family law and their meanings in lives lived beyond the court. The positionings of courts, and indeed of judges, are examined through frames beyond the substance (or text) of rulings. Increasing attention is paid to the way in which "lay" people - litigants, petitioners, their voices emerging from the historical record as well as from contemporaneous observation - act on their understandings of the law. Some of the most recent scholarship, nourished by and feeding into sustained dialogues and conversations, is purposively

\footnotetext{
${ }^{222}$ Al-Sharmani and Rumminger (2015) 226.

${ }^{223}$ Al-Sharmani and Rumminger (2015) 233.

${ }^{224}$ Sonneveld (2012); Shehada (2009); Al-Sharamani (2013); Bedner and Van Huis (2010) 184-85; Larsen (2015).

${ }^{225}$ Fawzi (2004); Hammami (2004); Hammami and Johnson (2013).

${ }^{226}$ Hammami and Johnson (2013) 11.
} 
constructed to produce fundamentally new paradigms and ways of thinking about law, authority and indeed the family. New voices and new critiques, as well as new challenges, are demanding attention; critiques of past frames, practice and scholarship continue to inform and indeed to correct; but right now, most eyes are on those who can go some way to proposing how these challenges might be met.

\section{List of References}

Abdal-Rehim, Abdal-Rehim Abdal-Rahman. "The Family and Gender Laws in Egypt during the Ottoman Period." In Women, the Family, and Divorce Laws in Islamic History, ed. Amira El Azhary Sonbol, 96-111. Syracuse: Syracuse University Press, 1996.

Abdul Kodir, Faqihuddin. "Gender Equality and the Hadith of the Prophet Muhammad. Reinterpreting the Concepts of Mahram and Qiwama." In Gender and Equality in Muslim Family Law. Justice and Ethics in the Islamic Legal Tradition, eds. Ziba Mir-Hosseini, Kari Vogt, Lena Larsen and Christian Moe, 169-189. London: I.B.Tauris 2013.

Abou-Bakr, Omaima. "The Interpretive Legacy of Qiwama as an Exegetical Construct.” In Men in Charge? Rethinking Authority in Muslim Legal Tradition, eds. Ziba Mir-Hosseini, Mulki Al-Sharmani and Jana Rumminger, 44-64. London: Oneworld, 2015.

Abu-Lughod, Lila. Do Muslim Women Need Saving? Cambridge, Mass.: Harvard University Press, 2013.

Abu-Lughod, Lila and Anupuma Rao (eds), Women's Rights, Muslim Family Law and the Politics of Consent, socialdifference-online 12011.

Abu-Odeh, Lama. "Modernizing Muslim Family Law: the case of Egypt," Vanderbilt Journal of Transnational Law 37 (2004) 1043.

Abu-Zayd, Nasr. "The Status of Women between the Qur' an and Fiqh." In Gender and Equality in Muslim Family Law. Justice and Ethics in the Islamic Legal Tradition, eds. Ziba Mir-Hosseini, Kari Vogt, Lena Larsen and Christian Moe, 153-168. London: I.B.Tauris 2013.

Agmon, Iris. "Muslim Women in Court According to the Sjill of Late Ottoman Jaffa and Haifa: some methodological notes." In Women, the Family and Divorce Laws in Islamic History, ed. Amira Sonbol, 112-125. Syracuse: Syracuse University Press, 1996.

Ahmad, Nehaluddin. "A Critical Appraisal of 'Triple Divorce' in Islamic Law." International Journal of Law, Policy and the Family 23/1 (2009) 53-61. 
Ahmed, Leila. Women and Gender in Islam, New Haven: Yale University Press, 1992.

Ahmed, Nausheen. "Family Law in Pakistan. Using the secular to influence the religious." In Adjudicating Family Law in Muslim Courts, ed. Elisa Giunchi, 70-86. Abingdon: Routledge 2014.

Ali, Kecia. "Marriage in Classical Islamic Jurisprudence. A Survey of Doctrines." In The Islamic Marriage Contract. Case Studies in Islamic Family Law, eds. Asifa Quraishi and Frank E. Vogel, 11-45. Cambridge, Mass.: Harvard University Press, 2008.

Ali, Shaheen Sardar. "From Muslim Migrants to Muslim Citizens." In Islam and English Law. Rights, Responsibilities and the Place of Shari 'a, ed. Robin Griffiths-Jones, 157-75. Cambridge: CUP, 2013.

- Gender and Human Rights in Islam and International Law. Equal before Allah, Unequal before Man? The Hague: Kluwer Law international, 2000.

Allie, Shouket. "A Legal and Historical Excursis of Muslim Personal Law in the Colonial Cape South Africa, Eighteenth to Twentieth Century." In Muslim Family Law in SubSaharan Africa. Colonial Legacies and Post-Colonial Challenges, ed. Shamil Jeppie, Ebrahim Moosa and Richard Roberts, 63-84. Amsterdam: Amsterdam University Press, 2010.

Al-Sharmani, Mulki. “Qiwama in Egyptian Family Laws: 'Wifely Obedience' between Legal Texts, Courtroom Practices and Realities of Marriage.” In Gender and Equality in Muslim Family Law. Justice and Ethics in the Islamic Legal Tradition, eds. Ziba Mir-Hosseini, Kari Vogt, Lena Larsen and Christian Moe, 37-55. London: I.B.Tauris 2013.

Al-Sharmani, Mulki. "Egyptian Khul': Legal Reform, Courtroom Practices, and Realities of Women." In Interpreting Divorce Laws in Islam, eds. Rubya Mehdi, Werner Menski and Jorgen S. Nielsen, 85-104. Copenhagen: DJOF Publishing, 2012.

- Ed. Feminist Activism, Women's Rights, and Legal Reform, London: Zed Books, 2013.

- - "Reforming Egyptian Family Laws: The Debate about a New Substantive Code." In Feminist Activism, Women's Rights, and Legal Reform, ed. Mulki Al-Sharmani, 73100.London: Zed Books, 2013.

Al-Sharmani, Mulki and Jana Rumminger. "Understanding Qiwamah and Wilayah through Life Stories.” In Men in Charge? Rethinking Authority in Muslim Legal Tradition, eds. Ziba Mir-Hosseini, Mulki Al-Sharmani and Jana Rumminger, 219-55. London: Oneworld, 2015.

Amin, Waheeda, "The Gendered Benefits and Costs of Legal Pluralism for Muslim Family Law in South Africa," In Managing Family Justice in Diverse Societies, ed. Mavis Maclean and John Eekelaar, 107-123. Oxford and Portland ,Oregon: Hart Publishing, 2013. 
Anderson, JND. Islamic Law in Africa. London: HMSO, 1954.

- "Invalid and Void Marriages in Hanafi Law." BSOAS 13/2 (1950) 357-366.

- "Recent Developments in Shari a Law (III): The Contract of Marriage." Muslim World 41 (1951) 35-48.

- "Recent Developments in Shari a Law (IV): Further Points Concerning Marriage." Muslim World 41 (1951) 186-98.

- "Recent Developments in Shari a Law (V): The Dissolution of Marriage." Muslim World 41 (1951) 271-288.

- "Recent Developments in Shari a Law (VI): The Testamentary Bequests." Muslim World 42 (1952) 33-47.

- "Recent Developments in Shari a Law (VII): Intestate Succession." Muslim World 42 (1952) 124-40.

- "Recent Developments in Shari a Law (VIII): The Jordanian Law of Family Rights." Muslim World 42 (1952) 190-206.

- "The Syrian Law of Personal Status." BSOAS 17 (1955), 34-49.

- “A Law of Personal Status for Iraq." ICLQ 9 (1960) 542-63.

- Law Reform in the Muslim World. London: The Athlone Press, 1976.

Anderson, Michael. "Islamic Law and the Colonial encounter in British India." In Islamic Family Law, eds. Chibli Mallat and Jane Connors, 205-223. London: Graham and Trotman, 1990.

An-Na im, Abdullahi, ed. London and New York: Zed Books, 2002.

- "Shari a and Islamic Family Law: Transition and Transformation." In Islamic Family Law in a Changing World. A Global Resource Book, ed. Abdullahi An-Na im, 1-22. London and New York: Zed Books

Anwar, Zainah. "From Local to Global: Sisters in Islam and the Making of Musawah: A Global Movement for Equality in the Muslim Family." In Men in Charge? Rethinking Authority in Muslim Legal Tradition, eds. Ziba Mir-Hosseini, Mulki Al-Sharmani and Jana Rumminger, 107-124. London: Oneworld, 2015.

- "Advocacy for Reform in Islamic Family Law: the Experience of Sisters in Islam." In The Islamic Marriage Contract. Case Studies in Islamic Family Law, eds. Asifa Quraishi and Frank E. Vogel, 273-84. Cambridge, Mass.: Harvard University Press, 2008.

Al-Azri, Khalid M.. Social and Gender Inequality in Oman. The power of religious and political tradition. Abingdon: Routledge 2013.

Arabi, Oussama. Studies in Modern Islamic Law and Jurisprudence. The Hague: Kluwer Law International, 2001.

Arshad, Raffia. Islamic Family Law. London: Sweet and Maxwell 2010. 
Baderin, Mashood ed. Issues in Islamic Law. Farnham, Surrey: Ashgate Publishing Limited, 2014.

Bakht, Natasha. "Family Arbitration Using Sharia Law: Examining Ontario's Arbitration Act and its Impact on women." Muslim World Journal of Human Rights 1/ 1, article 7 (2004).

Bano, Samia, "The practice of law making and the problem of forced marriage: what is the role of the Muslim Arbitration Tribunal?" In Forced marriage. Introducing a Social Justice and Human Rights Perspective, eds. Aisha K. Gill and Sundari Anitha, 177-199. London: Zed Books, 2011.

- "Muslim Women, Divorce and Shari ah Councils in Britain." In Interpreting Divorce Laws in Islam, eds. Rubya Mehdi, Werner Menski and Jorgen S. Nielsen, 259-288. Copenhagen: DJOF Publishing, 2012.

- "Muslim Dispute Resolution in Britain: Towards a New Framework of Family Law Governance?” In Managing Family Justice in Diverse Societies, eds. Mavis Maclean and John Eekelaar, 61-86. Oxford and Portland ,Oregon: Hart Publishing, 2013.

Bedner, Adriaan and Stijn van Huis. "Plurality of marriage law and marriage registration for Muslims in Indonesia: a plea for pragmatism." Utrecht Law Review Vol. 6 Issue 2 (2010) 175-191.

Berger, Maurits S. ed. Applying Shari 'a in the West. Facts, Fears and the Future of Islamic Rules on Family Relations in the West. Leiden: Leiden University Press, 2013.

Bernard-Maugiron, Nathalie. "The Judicial Construction of the Facts and the Law. The Egyptian Supreme Constitutional Court and the Constitutionality of the Law on Khul ." In Narratives of Truth in Islamic Law, eds. Baudouin Dupret, Barbara Drieskens and Annelies Moors, 241-264. London and New York: I.B.Tauris 2008.

- "Courts and the Reform of Personal Status Law in Egypt: Judicial divorce for injury and polygamy." In Adjudicating Family Law in Muslim Courts, ed. Elisa Giunchi, 106-120. Abingdon: Routledge, 2014.

Bowen, John. "Fairness and Law in an Indonesian Court." In Dispensing Justice in Islam. Qadis and their Judgements, eds. Muhammad Khalid Masud, Rudolph Peters, and David Powers, 118-14. Brill: Leiden, 2006, 2012.

Boyd, Marion. "Ontario's 'shari'a court': law and politics intertwined." In Islam and English Law. Rights, Responsibilities and the Place of Shari 'a, ed. Robin Griffiths-Jones, 176-186. Cambridge: CUP, 2013.

Butler-Sloss, Elizabeth and Mark Hill. "Family law: current conflicts and their resolution." In Islam and English Law. Rights, Responsibilities and the Place of Shari 'a, ed. Robin GriffithsJones, 108-115. Cambridge: CUP, 2013. 
Carlisle, Jessica. "Moroccan Divorce Law, Family Court Judges, and Spouses' claims: who Pays the Cost When a Marriage is Over?" In Feminist Activism, Women's Rights, and Legal Reform, ed. Mulki Al-Sharmani, 151-176. London: Zed Books, 2013.

Carroll, Lucy “Marriage-Guardianship and Minor's Marriage at Islamic Law” Islamic and Comparative Law Quarterly 7 (1987) 249-260.

Carroll, Lucy and Harsh Kapoor. Talaq-i-Tafwid: The Muslim Woman's Contractual Access to Divorce. An Information Kit. WLUML 1996 (np).

Charrad, Mounira. States and Women's Rights. The making of postcolonial Tunisia, Algeria and Morocco, Berkeley: University of California Press, 2001.

Chaudhry, Ayesha S. "Producing Gender-Egalitarian Islamic Law: A Case Study of Guardianship (Wilayah) in Prophetic Practice.” In Men in Charge? Rethinking Authority in Muslim Legal Tradition, eds. Ziba Mir-Hosseini, Mulki Al-Sharmani and Jana Rumminger, 88-105. London: Oneworld, 2015.

Chowdhury, Farah Deeba. "Muslim Family Law in Bangladesh: Resistance to Secularisation." In Managing Family Justice in Diverse Societies, eds. Mavis Maclean and John Eekelaar, 263-269. Oxford and Portland ,Oregon: Hart Publishing, 2013.

Cole, Juan. "Struggles over Personal Status and Family Law in Post-Baathist Iraq." In Family, Gender and Law in a Globalizing Middle East and South Asia, eds. Kenneth M. Cuno and Manisha Desai, 105-125. Syracuse: Syracuse University Press 2009.

Collectif 95 Maghreb-Egalité. Guide to Equality in the Family in the Maghreb, Women's Learning Partnership (nl) 2005.

Coulson, Noel J., Conflicts and Tensions in Islamic Jurisprudence. Chicago: University of Chicago Press 1969.

Cuno, Kenneth M.. Modernizing Marriage. Family, Ideology, and Law in Nineteenth- and Early Twentieth-Century Egypt, Syracuse: Syracuse University Press, 2015.

Cuno, Kenneth M. and Manisha Desai, eds. Family, Gender and Law in a Globalizing Middle East and South Asia Syracuse: Syracuse University Press 2009.

Dahlgren, Suzanne. "'She brings up Healthy Children for the Homeland': Morality Discourses in Yemeni Legal Debates." In Family Law in Islam. Divorce, Marriage and Women in the Muslim World, ed. Maaike Vooerhoeve, 13-20. London and New York: I. B. Tauris, 2012.

- ' 'Readjusting Women's Too Many Rights: The State, the Public Voice, and Women's Rights in South Yemen." In Feminist Activism, Women's Rights, and Legal Reform, ed. Mulki Al-Sharmani, 48-72. London: Zed Books, 2013. 
- Davis, John. “A Social Perspective.” In Legal Documents on Libyan Tribal Society in Process of Sedentarization (Part I: Documents in Arabic), ed. Aharon Layish, 7-13. Wiesbadan: Harrassowitz (1998).

Dupret, Baudouin. "What is Islamic Law? A Praxiological Answer and an Egyptian Case Study," Theory, Culture and Society 24/2 (2007) 79-100.

- "The Practice of Judging: The Egyptian Judiciary at Work on a Personal Status Case." In Dispensing Justice in Islam. Qadis and their Judgements, eds. Khalid Masud, Rudolph Peters, and David Powers, 143-168. Brill: Leiden 2012.

Dupret, Baudouin and Maaike Voorhoeve. "Introduction." In Family Law in Islam. Divorce, Marriage and Women in the Muslim World, ed. Maaike Vooerhoeve, 1-9. London and New York: I. B. Tauris, 2012.

Dupret, Bauduoin, Barbara Drieskens and Annelies Moors, eds. Narratives of Truth in Islamic Law. London and New York: I.B.Tauris 2008.

Edge, Ian. "Islamic finance, alternative dispute resolution and family law: developments towards legal pluralism?" In Islam and English Law. Rights, Responsibilities and the Place of Shari `a, ed. Robin Griffiths-Jones, 116-143. Cambridge: CUP, 2013.

Eijk, Esther van. "Divorce Practices in Muslim and Christian Courts in Syria." In Family Law in Islam. Divorce, Marriage and Women in the Muslim World, ed. Maaike Vooerhoeve, 147170. London and New York: I. B. Tauris, 2012.

- Family Law in Syria. Patriarchy, Pluralism and Personal Status Law. London and New York: I. B. Tauris forthcoming (2016)

El Alami, Dawoud. The Marriage Contract in Islamic Law, in the Shari'ah and Personal Status Laws of Egypt and Morocco. London: Graham and Trotman 1992.

- "Remedy or Device? The System of Khul' and the Effects of its Incorporation into Egyptian Personal Status Law." Yearbook of Islamic and Middle Eastern Law 9 (1999-2000) 134-35.

El Alami, Dawoud and Doreen Hinchcliffe. Islamic Marriage and Divorce Laws of the Arab World. London: Kluwer Law International 1996, reprinted 1998.

El Hajjami, Aicha. "The Religious Arguments in the Debate on the Reform of the Moroccan Family Code." In Gender and Equality in Muslim Family Law. Justice and Ethics in the Islamic Legal Tradition, eds. Ziba Mir-Hosseini, Kari Vogt, Lena Larsen and Christian Moe, 81-105. London: I.B.Tauris 2013.

Emon, Anver M., Mark S. Ellis and Benjamin Glahn eds. Islamic Law and International Human Rights Law. Searching for Common Ground? Oxford: OUP 2012. 
Emon, Anver. "The Paradox of Equality and the Politics of Difference. Gender Equality, Islamic Law and the Modern Muslim State." In Gender and Equality in Muslim Family Law. Justice and Ethics in the Islamic Legal Tradition, eds. Ziba Mir-Hosseini, Kari Vogt, Lena Larsen and Christian Moe, 237-258. London: I.B.Tauris 2013.

Eshkevari, Hassan Yousefi. "Rethinking Men's Authority Over Women. Qiwama, Wilaya and their Underlying Assumptions." In Gender and Equality in Muslim Family Law. Justice and Ethics in the Islamic Legal Tradition, eds. Ziba Mir-Hosseini, Kari Vogt, Lena Larsen and Christian Moe, 191-211. London: I.B.Tauris 2013.

Esposito, John L. with Natana J. DeLong-Bas. Women in Muslim Family Law. Syracuse: Syracuse University Press, 2001.

Fawzy, Essam. "Muslim Personal Status Law in Egypt: the current situation and possibilities of reform through internal initiatives." In Women's Rights and Islamic Family Law.

Perspectives on Reform, ed. Lynn Welchman, 17-94. London and New York: Zed Books, 2004.

Fierro, Maribel. "Ill-treated Women Seeking Divorce: The Quranic Two Arbiters and Judicial Practice among the Malikis of al-Andalus and North Africa." In Dispensing Justice in Islam. Qadis and their Judgements, eds. Muhammad Khalid Masud, Rudolph Peters, and David Powers, 324-347. Brill: Leiden, 2012.

Foblets, Marie-Claire. "The Admissibility of Repudiation: Recent Developments in Dutch, French and Belgian Private Law." Hawwa 5,1 (2007) 10-32.

- "Accommodating Islamic Family Law(s): A Critical Analysis of Some Recent Developments and Experiments in Europe." In Applying Shari a in the West. Facts, Fears and the Future of Islamic Rules on Family Relations in the West, ed. Maurits S. Berger, 207-226. Leiden: Leiden University Press, 2013.

- "Marriage and Divorce in the New Moroccan Family Code: Implications for Moroccans residing in Europe." In Law and Religion in Multicultural Societies, ed. Rubya Mehdi, Hanne Petersen, Erik Reenberg Sand and Gordon R. Woodman, 14574. Copenhagen: DJOF Publishing, 2008.

Fournier, Pascale. Muslim Marriage in Western Courts. Lost in Transplantation. Farnham, Surrey: Ashgate, 2010.

Fournier, Pascale, Aida Setrakian and Pascal McDougall. "No-Fault Talaq: Islamic Divorce in Canadian Immigration and Family Law." In Interpreting Divorce Laws in Islam, eds. Rubya Mehdi, Werner Menski and Jorgen S. Nielsen, 235-258. Copenhagen: DJOF Publishing, 2012.

Freeland, Richard and Martin Lau. "The Shari`a and English Law: Identity and Justice for British Muslims.” In The Islamic Marriage Contract. Case Studies in Islamic Family Law, eds. Asifa Quraishi and Frank E. Vogel, 331-347. Cambridge, Mass.: Harvard University Press, 2008. 
Fyzee, Asaf A.A.. Outlines of Muhammadan Law. New Delhi: OUP India, 1949, 1955, 1964, 1974, 1999.

Ghanea, Nazila. "Rights, Women and Human Rights Change in Iran." In Managing Family Justice in Diverse Societies, eds. Mavis Maclean and John Eekelaar, 247-261. Oxford and Portland, Oregon: Hart Publishing, 2013.

Gill, Aisha K. And Sundari Anitha (eds), Forced marriage. Introducing a Social Justice and Human Rights Perspective, London: Zed Books, 2011.

Gilani, Riazul Hasan. "A Note on Islamic Family Law and Islamization in Pakistan.” In Islamic Family Law, eds. Chibli Mallat and Jane Connors, 339-346. London: Graham and Trotman, 1990.

Giunchi, Elisa ed. Adjudicating Family Law in Muslim Courts. Abingdon: Routledge 2014.

Griffiths-Jone, Robin (ed). Islam and English Law. Rights, Responsibilities and the Place of Shari 'a. Cambridge: CUP 2013.

- " "The 'unavoidable' adoption of shari a law - the generation of a media storm." In Islam and English Law. Rights, Responsibilities and the Place of Shari 'a, ed. Robin Griffiths-Jones 9-19. Cambridge: CUP, 2013.

Grillo, Ralph D. "In the Shadow of the Law: Muslim Marriage and Divorce in the UK." In Interpreting Divorce Laws in Islam, eds. Rubya Mehdi, Werner Menski and Jorgen S. Nielsen, 203-233. Copenhagen: DJOF Publishing, 2012.

Haeri, Shahla. Law of Desire: temporary marriage in Shi i Iran. New York: Syracuse University Press, 1989.

- "Mut'a: Regulating Sexuality andGender Relations in Postrevolutionary Iran." In Islamic Legal Interpretation. Muftis and their Fatwas, eds. Muhammad Khalid Masud, Brinkley Messick and David S. Powers, 251-261. Cambridge, Massachusetts: Harvard University Press 1996.

- "Divorce in Contemporary Iran: A Male Prerogative in Self-Will." In Islamic Family Law, eds. Chibli Mallat and Jane Connors, 55-69. London: Graham and Trotman, 1990.

Hammami, Rema. "Attitudes towards legal reform of personal status law in Palestine." In Women's Rights and Islamic Family Law. Perspectives on Reform, ed. Lynn Welchman, 125143. London and New York: Zed Books, 2004.

Hammami, Rema and Penny Johnson. Change and Conservation: Family Law Reform in Court Practice and Public Perceptions in the Occupied Palestinian Territory. Birzeit: Institute of Women's Studies, December 2013. 
Hanna, Nelly. "Marriage among Merchant Families in Seventeenth-Century Cairo." In Women, the Family and Divorce Laws in Islamic History, ed. Amira Sonbol, 143-154. Syracuse: Syracuse University Press, 1996.

Hassan, Sharifah Zaleha Syed and Sven Cederroth. Managing Marital Disputes in Malaysia. Islamic Mediators and Conflict Resolution in the Syariah Courts, Richmond: Curzon (1997).

Hasso, Frances. "Bargaining with the Devil. States and Intimate Life." Journal of Middle East Women's Studies 10,2 (2014) 107-134.

- Consuming Desires. Family Crisis and the State in the Middle East. Stanford: Stanford University Press 2011.

Hegel-Cantarella, Christine. "Waiting to Win: Family Disputes, Court Reform, and the Ethnography of Delay." In Family Law in Islam. Divorce, Marriage and Women in the Muslim World, ed. Maaike Vooerhoeve, 111-147. London and New York: I. B. Tauris, 2012. al-Hibri, Azizah. "Islam, Law and Custom. Redefining Muslim Women's Rights." American University Journal of International Law and Policy 12,1 (1997) 1-44.

- "Muslim Women's Rights in the Global Village: Challenges and Opportunities." Journal of Law and Religion 15, 1-2 (2000) 37-66.

Hinchcliffe, Doreen. "Polygamy in Traditional and Contemporary Islamic Law." Islam and the Modern Age 1/8 (1970) 13-38.

Hirsch, Susan. "Islamic Law and Society Post-9/11." Annu. Rev. Law Soc. Sci. 2006 2:16586.

- Pronouncing and Persevering. Gender and the Discourses of Disputing in an African Islamic Court, Chicago: University of Chicago Press, 1998.

- "State Intervention in Muslim Family Law in Kenya and Tanzania: Applications of the Gender Concept.” In Muslim Family Law in Sub-Saharan Africa. Colonial Legacies and Post-Colonial Challenges, ed. Shamil Jeppie, Ebrahim Moosa and Richard Roberts, 305-30. Amsterdam: Amsterdam University Press, 2010.

Holden, Livia. "Divorce at the Woman's Initiative in India, in Pakistan and in the Diasporas." In Interpreting Divorce Laws in Islam, ed. Rubya Mehdi, Werner Menski and Jorgen S. Nielsen, 131-53. Copenhagen: DJOF Publishing, 2012.

Hoodfar, Homa, ed. Shifting Boundaries in Marriage and Divorce in Muslim Communities, WLUML: 1996 (np)

Hossain, Sara "Remedies for forced marriage in Bangladesh." In Remedies for Forced Marriage: A Handbook for Lawyers, eds. Sara Hossain and Lynn Welchman. London: INTERIGHTS, 2014 (available at http://www.interights.org/forced-marriagehandbook/index.html). 
- “'Wayward girls and well-wisher parents': habeas corpus, women's right to personal liberty, consent to marriage and the Bangladeshi courts." In Forced marriage. Introducing a Social Justice and Human Rights Perspective, eds. Aisha K. Gill and Sundari Anitha, 221-240. London: Zed Books, 2011.

Hossain, Sara and Lynn Welchman (eds), Remedies for Forced Marriage: A Handbook for Lawyers, London: INTERIGHTS 2014) (available at http://www.interights.org/forcedmarriage-handbook/index.html)

Huxley, Andrew. "Khaek, Moro, Rohingo - The Family Law of Three South East Asian Muslim Minorities." In Islamic Family Law, eds. Chibli Mallat and Jane Connors, 225-52. London: Graham and Trotman, 1990.

Human Rights Watch. “Divorced from Justice: Women's Unequal Access to Divorce in Egypt.” HRW: 2004.

- “'How Come You Allow Little Girls to Get Married?' Child Marriage in Yemen." HRW: 2011.

"Unequal and Unprotected. Women's Rights Under Lebanese Personal Status Law." HRW: 2015.

Ivanova, Svetlana. "The Divorce Between Zubaida Hataun and Esseid Osman Aga: Women in the Eighteenth-Century Shari a Court of Rumelia." In Women, the Family and Divorce Laws in Islamic History, ed. Amira Sonbol, 1126-140. Syracuse: Syracuse University Press, 1996.

- Jeppie, Shamil, Ebrahim Moosa and Richard Roberts eds. Muslim Family Law in SubSaharan Africa. Colonial Legacies and Post-Colonial Challenges, ed. Shamil Jeppie, Ebrahim Moosa and Richard Roberts, 305-30. Amsterdam: Amsterdam University Press, 2010. And "Introduction"13-60.

Johansen, Baber. "The Constitution and the Principles of Islamic Normativity Against the Rules of Fiqh." In Dispensing Justice in Islam. Qadis and their Judgements, eds. Muhammad Khalid Masud, Rudolph Peters, and David Powers, 169-193. Brill: Leiden, 2012.

Jones-Pauly, Christina. "Marriage Contracts of Muslims in the Diaspora. Problems in the Recognition of Mahr Contracts in German Law." In The Islamic Marriage Contract. Case Studies in Islamic Family Law, eds. Asifa Quraishi and Frank E. Vogel, 299-330. Cambridge, Mass.: Harvard University Press, 2008.

Kadivar, Mohsen. "Revisiting Women's Rights in Islam. 'Egalitarian Justice in Lieu of 'Desserts-based Justice." In Gender and Equality in Muslim Family Law. Justice and Ethics in the Islamic Legal Tradition, eds. Ziba Mir-Hosseini, Kari Vogt, Lena Larsen and Christian Moe, 213-234. London: I.B.Tauris 2013. 
Kapur, Ratna. 'Unveiling Equality: Disciplining the 'Other' Woman Through Human Rights Discourse.” In Islamic Law and International Human Rights Law. Searching for Common Ground? Eds. Anver M. Emon, Mark S. Ellis and Benjamin Glahn, 265-290. Oxford: OUP 2012.

Khadduri, Majid. "Marriage in Islamic Law: The Modernist Viewpoints." American Journal of Comparative Law 26 (1978) 213-18.

Khan, Fareeha. "Tafwid al-Talaq: Transferring the Right to Divorce to the Wife." Muslim World 99/3 (2009) 502-20.

'Kola, Abdul-Fatah Makinde. "Women and Divorce: The Position of the Shari'ah." Islamic Quarterly 54/3 (2010) 249-60.

Lamrabet, Asma. "An Egalitarian Reading of the Concepts of Khilafah, Wilayah and Qiwamah." In Men in Charge? Rethinking Authority in Muslim Legal Tradition, eds. Ziba Mir-Hosseini, Mulki Al-Sharmani and Jana Rumminger, 65-87. London: Oneworld, 2015.

Largueche, Dalenda. "Monogamy in Islam: The Case of a Tunisian Marriage Contract." Institute of Advanced Studies, School of Social Science Occasional Papers, 39 (September 2010) available at: http://www.sss.ias.edu/files/papers/paper39.pdf

Larsen, Lena. "Men are the Protectors and Maintainers of Women...' Three Fatwas on Spousal Roles and Rights.” In Men in Charge? Rethinking Authority in Muslim Legal Tradition, eds. Ziba Mir-Hosseini, Mulki Al-Sharmani and Jana Rumminger, 197-218. London: Oneworld, 2015.

Lawyers Collective, Asmitu Basu and Jayna Kothari, "Remedies for forced marriage in India." In Remedies for Forced Marriage: A Handbook for Lawyers, eds. Sara Hossain and Lynn Welchman. London: INTERIGHTS, 2014 (available at http://www.interights.org/forced-marriage-handbook/index.html).

Layish, Aharon. Women and Islamic Law in a Non-Muslim State. A Study Based on Decisions of the Shari a Courts in Israel. New York: John Wiley and Sons, Jerusalem: Israel Universities Press, 1975.

- Shari a and Custom in Libyan Tribal Society. An annotated Translation of Decisions from the Shari a Courts of Adjabiya and Kufra. Leiden, Boston: Brill 2005.

- Legal Documents on Libyan Tribal Society in Process of Sedentarization (Part I: Documents in Arabic). Wiesbadan: Harrassowitz (1998).

Lindbekk, Monika. "The Enforcement of Personal Status Law by Egyptian Courts." In Adjudicating Family Law in Muslim Courts, ed. Elisa Giunchi, 87-105. Abingdon: Routledge, 2014. 
Liversage, Anika. "Muslim Divorces in Denmark - Findings from an Empirical Investigation." In Interpreting Divorce Laws in Islam, eds. Rubya Mehdi, Werner Menski and Jorgen S. Nielsen, 179-201. Copenhagen: DJOF Publishing, 2012.

Longinotto, Kim and Ziba Mir-Hosseini, Divorce Iranian-Style. New York: Women Make Movies, 1998.

Lydon, Ghislaine. "Obtaining Freedom at the Muslims' Tribunal. Colonial Kadijustiz and Women's Divorce in Ndar (Senegal)." In Muslim Family Law in Sub-Saharan Africa.

Colonial Legacies and Post-Colonial Challenges, ed. Shamil Jeppie, Ebrahim Moosa and Richard Roberts, 135-64. Amsterdam: Amsterdam University Press, 2010.

Maclean, Mavis and John Eekelaar. Managing Family Justice in Diverse Societies. Oxford and Portland Oregon: Hart Publishing, 2013.

Mahmood, Tahir. Statutes of Personal Law in Islamic Countries. History, Texts and Analysis. Delhi: ALR 1987, 1995.

- Family Law Reform in the Muslim World. Delhi: Indian Law Institute, 1972.

- "Islamic Family law. Latest Developments in India." In Islamic Family Law, eds Chibli Mallat and Jane Connors, 295 - 320. London: Graham and Trotman, 1990.

Mallat, Chibli and Jane Connors, eds. Islamic Family Law, London: Graham and Trotman, 1990.

Maktabi, Rania. "Female Citizenship in the Middle East: comparing family law reform in Morocco, Syria and Lebanon." Middle East Law and Governance 5 (2013) 1-28.

Mashhour, Amira. "Islamic Law and Gender Equality. Could there be a Common Ground? A Study of Divorce and Polygamy in Sharia Law and Contemporary Legislation in Tunisia and Egypt." Human Rights Quarterly 27,2 (2005) 562-96.

Masud, Khalid. "The Award of Mata' in the Early Muslim Courts." In Dispensing Justice in Islam. Qadis and their Judgements, eds. Khalid Masud, Rudolph Peters, David Powers. Brill: Leiden 2012.

- “Apostasy and Judicial Separation.” In Islamic Legal Interpretation. Muftis and their Fatwas, eds Muhammad Khalid Masud, Brinkley Messick and David Powers. Cambridge, Massachusetts: Harvard University Press 1996.

- "Gender Equality and the Doctrine of Wilaya." in Gender and Equality in Muslim Family Law. Justice and Ethics in the Islamic Legal Tradition, eds Mir-Hosseini et al, 127-152. London: I.B.Tauris 2013.

Masud, Muhammad Khalid, Brinkey Messick, David S. Powers (eds). Islamic Legal Interpretation. Muftis and their Fatwas. Cambridge, Massachusetts: Harvard University Press 1996. And: "Muftis, Fatwas and Islamic Legal Interpretation." 
Masud, Muhammad Khalid, Rudolph Peters, David Powers (eds). Dispensing Justice in Islam. Qadis and their Judgements. Brill: Leiden 2006, 2012.

Mayer, Ann Elizabeth. "Reform of Personal Status Laws in North Africa. A Problem of Islamic or Mediterranean laws?” Middle East Journal 49/3 1995.

Mehdi, Rubya, Werner Menski and Jorgen S. Nielsen (eds). Interpreting Divorce Laws in Islam, Copenhagen: DJOF Publishing, 2012.

Mehdi, Rubya, Hanne Petersen, Erik Reenberg Sand and Gordon R. Woodman, eds. Law and Religion in Multicultural Societies. Copenhagen: DJOF Publishing, 2008.

Messick, Brinkley. The Calligraphic State. Textual Domination and History in a Muslim Society, Berkeley: University of California Press 1992.

- "Interpreting Tears: A Marriage Case from Islamic Yemen." In The Islamic Marriage Contract. Case Studies in Islamic Family Law, ed. Asifa Quraishi and Frank E. Vogel, 156-179. Cambridge, Mass.: Harvard University Press, 2008.

Mir-Hosseini, Ziba. Marriage on Trial. A Study of Islamic Family Law. London: I.B.Tauris, 1993.

- "Muslim Legal Tradition and the Challenge of Gender Equality." In Men in Charge? Rethinking Authority in Muslim Legal Tradition. In eds. Mir-Hosseini, Ziba, Mulki Al-Sharmani and Jana Rumminger, 13-43. London: Oneworld, 2015.

Mir-Hosseini, Ziba, Kari Vogt, Lena Larsen and Christian Moe eds. Gender and Equality in Muslim Family Law. Justice and Ethics in the Islamic Legal Tradition. London: I.B.Tauris 2013. And "Introduction: Muslim Family Law and the Question of Equality." 1-6.

Mir-Hosseini, Ziba, Mulki Al-Sharmani and Jana Rumminger, eds. Men in Charge? Rethinking Authority in Muslim Legal Tradition. London: Oneworld, 2015. And "Introduction"1-12.

Mir-Hosseini, Ziba. "Women in Search of Common Ground: Between Islamic and International Human Rights Law." In Islamic Law and International Human Rights Law. Searching for Common Ground?, eds. Anver M. Emon, Mark S. Ellis and Benjamin Glahn, 291-308. Oxford: OUP (2012).

- “A Woman's Right to Terminate the Marriage Contract: the case of Iran." In The Islamic Marriage Contract. Case Studies in Islamic Family Law, ed. Asifa Quraishi and Frank E. Vogel, 215-230. Cambridge, Mass.: Harvard University Press, 2008. 
Modirzadeh, Naz K. "Taking Islamic Law Seriously: INGOs and the Battle for Muslim Hearts and Minds." Harvard Human Rights Journal 19 (2006) 193-235.

Moors, Annelies. "Registering a Token Dower: the Multiple Meanings of a Legal Practice." In Narratives of Truth in Islamic Law, eds. Baudouin Dupret, Barbara Drieskens and Annelies Moors, 85-104. London and New York: I.B.Tauris 2008.

- "Unregistered Islamic Marriages: Anxieties about Sexuality and Islam in the Netherlands." In Applying Shari 'a in the West. Facts, Fears and the Future of Islamic Rules on Family Relations in the West, ed. Maurits S. Berger, 141-164. Leiden: Leiden University Press, 2013.

- Women, property and Islam. Palestinian experiences 1920-1990. CUP: 1995.

- "Debating Islamic Family Law: Legal Texts and Social Practices." In A Social History of Women and Gender in the Modern Middle East, eds. M. Meriwether and Judith Tucker, 141-175. Boulder: Westview, 1999.

Moosa, Ebrahim. "Muslim Family Law in South Africa: Paradoxes and Ironies." In Muslim Family Law in Sub-Saharan Africa. Colonial Legacies and Post-Colonial Challenges, ed. Shamil Jeppie, Ebrahim Moosa and Richard Roberts, 331-54. Amsterdam: Amsterdam University Press, 2010.

Motzki, Harald. "Child Marriage in Seventeenth-Century Palestine." In Islamic Legal Interpretation. Muftis and their Fatwas, eds Muhammad Khalid Masud, Brinkley Messick and David Powers, 129-149. Cambridge, Massachusetts: Harvard University Press, 1996.

Musawah. CEDAW and Muslim Family Laws: In Search of Common Ground. Petaling Jaya: Musawah 2011.

Muslim Marriage Contract (2008) available at http://www.muslimparliament.org.uk/Documentation/Muslim\%20Marriage\%20Contract.pdf

Nasir, Jamal. The Islamic Law of Personal Status. $1^{\text {st }}$ and $2^{\text {nd }}$ editions London: Graham and Trotman 1986, 1990. $3^{\text {rd }}$ Edition The Hague, London: Kluwer Law International 2001 (reprinted Leiden: Brill 2009).

- $\quad$ The Status of Women under Islamic law and Modern Legislation. $1^{\text {st }}$ and $2^{\text {nd }}$ editions London: Graham and Trotman 1990, 1994. $3^{\text {rd }}$ edition Leiden and Boston: Brill 2009.

Nazneen, Sohela. "Men Aboard? Movement for a Uniform Family Code in Bangladesh.” In Feminist Activism, Women's Rights, and Legal Reform, ed. Mulki Al-Sharmani, 101-124. London: Zed Books, 2013.

Newcomb, Rachel. “Justice for Everyone? Implementation of Morocco's 2004 Mudawana Reforms." In Interpreting Divorce Laws in Islam, eds. Rubya Mehdi, Werner Menski and Jorgen S. Nielsen, 105-127. Copenhagen: DJOF Publishing, 2012. 
Nielsen, Jorgen S. "An Early Discussion on Islamic Family Law in the English Jurisdiction." In Applying Shari ' $a$ in the West. Facts, Fears and the Future of Islamic Rules on Family Relations in the West, ed. Maurits S. Berger, 79-96. Leiden: Leiden University Press, 2013.

Osanloo, Arzoo. "What a Focus on 'Family' Means in the Islamic Republic of Iran." In Family Law in Islam. Divorce, Marriage and Women in the Muslim World, ed. Maaike Vooerhoeve, 51-75. London and New York: I. B. Tauris, 2012.

- 'From Status to Rights: The Shifting Dimensions of Women's Activism in Iranian Family Law Reform.” In Feminist Activism, Women's Rights, and Legal Reform, ed. Mulki Al-Sharmani, 125-150.London: Zed Books, 2013.

Pearl, David. "Three Decades of Executive Legislative and Judicial Amendments to Islamic Family Law in Pakistan." In Islamic Family Law, eds. Chibli Mallat and Jane Connors, 321337. London: Graham and Trotman, 1990.

Peirce, Leslie. Morality Tales: Law and Gender in the Ottoman Court of Aintab. Berkeley, CA: University of California Press, 2003.

Poulter, Sebastian. "The Claim to a Separate Islamic System of Personal Law for British Muslims." In Islamic Family Law, eds. Chibli Mallat and Jane Connors, 147-66. London: Graham and Trotman, 1990.

Powers, David. "Four Cases Relating to Women and Divorce in al-Andalus and the Maghrib, 1100-1500.” In Dispensing Justice in Islam. Qadis and their Judgements, eds. Muhammad Khalid Masud, Rudolph Peters, and David Powers, 383-409. Brill: Leiden, 2012.

Quraishi, Asifa and Frank Vogel, eds. The Islamic Marriage Contract. Case Studies in Islamic Family Law. Cambridge, Massachusetts: Harvard University Press, 2008.

Quraishi, Asifa and Najeeba Syeed-Miller. "No altars: a Survey of Islamic Family Law in the United States." In Women's Rights and Islamic Family Law. Perspectives on Reform, ed. Lynn Welchman, 177-229. London and New York: Zed Books, 2004.

Rapoport, Yossef. Marriage, Money and Divorce in Medieval Islamic Society. Cambridge: CUP, 2005.

- "Matrimonial Gifts in Early Islamic Egypt.” Islamic Law and Society 7,1 (2000), 136.

Rehman, Javaid. "The Sharia, Islamic Family Laws and International Human Rights Law: examining the theory and practice of polygamy and talaq." International Journal of Law, Policy and the Family 21 (2007) 108-127.

di Ricco, Massimo. "Reclaiming Changes within the Community Public sphere: Druze Women's Activism, Personal Status Law and the Quest for Lebanese Multiple Citizenship." 
In Family Law in Islam. Divorce, Marriage and Women in the Muslim World, ed. Maaike Voorhoeve, 31-49. London and New York: I. B. Tauris, 2012.

Rosen, Lawrence."Revision and Reality in the Family Law of Morocco." In Law and Religion in Multicultural Societies, ed. Rubya Mehdi, Hanne Petersen, Erik Reenberg Sand and Gordon R. Woodman, 131-144. Copenhagen: DJOF Publishing, 2008

Rutten, Susan. "Applying Shari a to Family Law Issues in the Netherlands." In Applying Shari ' ${ }^{\prime}$ in the West. Facts, Fears and the Future of Islamic Rules on Family Relations in the West, ed. Maurits S. Berger, 96-123. Leiden: Leiden University Press, 2013.

Sadiqi, Fatima. "The Potential Within: Adjudications on shiqaq (discord) divorce by Moroccan judges.” In Adjudicating Family Law in Muslim Courts, ed. Elisa Giunchi, 121135. Abingdon: Routledge 2014.

Said, Edward. Orientalism. London:Routledge \& Kegan Paul Ltd, 1978.

Salime, Zakia. "Revisiting the Debate on Family Law in Morocco. Contexts, Actors and Discourses." In Family, Gender and Law in a Globalizing Middle East and South Asia, eds. Kenneth M. Cuno and Manisha Desai, 145-162. Syracuse: Syracuse University Press 2009.

Sevgin, Yuksel. Human Rights under State-Enforced Religious Family Laws in Israel, Egypt and India. Cambridge: Cambridge University Press, 2013.

Semerdjian, Elyse. Off the Straight path. Illicit sex, law and community in Ottoman Aleppo. Syracuse: Syracuse University Press 2008.

Shah, Nik Noriani Nik Badli. "Legislative Provisions and Judicial Mechanisms for the Enforcement and Termination of the Islamic Marriage Contract in Malaysia." In The Islamic Marriage Contract. Case Studies in Islamic Family Law, ed. Asifa Quraishi and Frank E. Vogel, 183-199. Cambridge, Mass.: Harvard University Press, 2008.

Shah, Prakash. "Judging Muslims." In Islam and English Law. Rights, Responsibilities and the Place of Shari ‘a, ed. Robin Griffiths-Jones 214-56. Cambridge: CUP 2013.

Sharafeldin, Marwa. "Egyptian Women's rights NGOs: Personal Status Law Reform between Islamic and International Human Rights Law." In Gender and Equality in Muslim Family Law. Justice and Ethics in the Islamic Legal Tradition, eds. Ziba Mir-Hosseini, Kari Vogt, Lena Larsen and Christian Moe, 57-80. London: I.B.Tauris 2013.

- "Islamic Law Meets Human Rights: Reformulating Qiwamah and Wilayah for Personal Status Law Advocacy in Egypt.” In Men in Charge? Rethinking Authority in Muslim Legal Tradition, eds. Ziba Mir-Hosseini, Mulki Al-Sharmani and Jana Rumminger, 163-196. London: Oneworld, 2015. 
Shehada, Nahda. "Debating Islamic Family Law in Palestine: Citizenship, Gender and 'Islamic' Idioms." In Feminist Activism, Women's Rights, and Legal Reform, ed. Mulki AlSharmani, 23-47. London: Zed Books, 2013.

- "House of Obedience: Social Norms, Individual Agency and Historical Contingency." Journal of Middle East Women's Studies 5/1 (2009) 24-49.

Siddiqui, Dina. "Of consent and contradiction: forced marriages in Bangladesh." In 'Honour'. Crimes, paradigms and violence against women, eds. Lynn Welchman and Sara Hossain, 283-307. London: Zed Books 2005.

Siddiqui, Mona. "Mahr: Legal Obligation or Rightful Demand?” Journal of Islamic Studies 1 (1995) 14-24.

- "Law and the Desire for Social Control: An Insight into the Hanafi Concept of Kafa'a with Reference to the Fatawa 'Alamgiri (1664-1672)." In Feminism and Islam, ed. Mai Yamani, 49-68. London: Ithaca, 1996.

Sonbol, Amira El Azhary. "Adults and Minors in Ottoman Shari 'a Courts and Modern Law." In Women, the Family and Divorce Laws in Islamic History, Amira Sonbol ed., 236-56. Syracuse: Syracuse University Press, 1996.

- “Ta'a and Modern Legal Reform: A Re-reading," Islam and Christian-Muslim Relations 9:3 (1998) 285-294.

- " "A History of Marriage Contracts in Egypt." In The Islamic Marriage Contract. Case Studies in Islamic Family Law, ed. Asifa Quraishi and Frank E. Vogel, 87122. Cambridge, Mass.: Harvard University Press, 2008.

Sonneveld, Nadia. Khul Divorce in Egypt. Public Debates, Judicial Practices, and Everyday Life. Cairo: American University in Cairo Press, 2012.

- "Rethinking the Difference between Formal and Informal Marriages in Egypt." In Family Law in Islam. Divorce, Marriage and Women in the Muslim World, ed. Maaike Voorhoeve, 77-107. London and New York: I. B. Tauris, 2012.

Stiles, Erin. "Broken Edda and Marital Mistakes: Two recent disputes from an Islamic Court in Zanzibar." In Dispensing Justice in Islam. Qadis and their Judgements, eds. Khalid Masud, Rudolph Peters and David Powers, 95-115. Brill: Leiden 2012.

Tucker, Judith E. In the House of the Law. Gender and Islamic Law in Ottoman Syria and Palestine. Berkeley: University of California Press, 1998.

- Women, Family and Gender in Islamic Law, Cambridge: CUP 2008.

- "Questions of Consent: Contracting a Marriage in Ottoman Syria and Palestine." In The Islamic Marriage Contract. Case Studies in Islamic Family Law, eds. Asifa 
Quraishi and Frank Vogel, 123-135. Cambridge, Massachusetts: Harvard University Press, 2008.

Turner, Bryan S. and James T. Richardson. "America: Islam and the Problems of Liberal democracy." In Applying Shari 'a in the West. Facts, Fears and the Future of Islamic Rules on Family Relations in the West, ed. Maurits S. Berger, 47-64. Leiden: Leiden University Press, 2013.

Vatuk, Sylvia. "The Application of Muslim Personal Law in India. A system of legal pluralism in action." In Adjudicating Family Law in Muslim Courts, ed. Elisa Giunchi, 48-69. Abingdon: Routledge 2014.

Vogel, Frank. "The Complementarity of Ifta' and Qada': Three Saudi Fatwas on Divorce.” In Islamic Legal Interpretation. Muftis and their Fatwas, eds. Muhammad Khalid Masud, Brinkley Messick and David S. Powers, 262-269. Cambridge, Massachusetts: Harvard University Press 1996.

Voorhoeve, Maaike. Gender and Divorce Law in North Africa. Sharia, Custom and the Personal Status Code in Tunisia. London and New York: I.B. Tauris 2014.

- Ed., Family Law in Islam. Divorce, Marriage and Women in the Muslim World. London and New York: I. B. Tauris, 2012. And "Judicial Discretion in Tunisian Personal Status Law," 199-229.

Wadud, Amina. "The Ethics of Tawhid over the Ethics of Qiwamah.” In Men in Charge? Rethinking Authority in Muslim Legal Tradition, eds. Ziba Mir-Hosseini, Mulki Al-Sharmani and Jana Rumminger, 256-274. London: Oneworld, 2015.

Warraich, Sohail, "Remedies for forced marriage in Pakistan." In Remedies for Forced Marriage: A Handbook for Lawyers, eds. Sara Hossain and Lynn Welchman, London: INTERIGHTS 2014 (available at http://www.interights.org/forced-marriagehandbook/index.html).

Weiss, Anita M. "Straddling CEDAW and the MMA. Conflicting Visions of Women's Rights in Contemporary Pakistan." In Family, Gender and Law in a Globalizing Middle East and South Asia, eds. Kenneth M. Cuno and Manisha Desai, 163-183. Syracuse: Syracuse University Press 2009.

Welchman, Lynn. "Family, Gender and Law in Jordan and Palestine." In Family, Gender and Law in a Globalizing Middle East and South Asia, eds. Kenneth M. Cuno and Manisha Desai, 126-144. Syracuse: Syracuse University Press 2009.

"Qiwamah and Wilayah as Legal Postulates in Muslim Family Laws." In Men in Charge? Rethinking Authority in Muslim Legal Tradition, eds. Ziba Mir-Hosseini, Mulki Al-Sharmani and Jana Rumminger, 132-162. London: Oneworld, 2015.

- Ed. Women's Rights and Islamic Family Law. Perspectives on Reform, London and New York: Zed Books, 2004. And: "Introduction" 1-14. 
- Beyond the Code. Muslim Family Law and the Shar ’ Judiciary in the Palestinian West Bank. The Hague: Kluwer Law International, 2000.

- "In the Interim: "In the Interim: Civil Society, the Shar'i Judiciary and Palestinian Personal Status Law in the Transitional Period." Islamic Law and Society 10,1 (2003) 34-69.

- Women and Muslim Family Laws in Arab States. A Comparative Overview of Textual Development and Advocacy, Amsterdam: Amsterdam University Press, 2007.

Williams, Rowan. "Civil and religious law in England: a religious perspective." In Islam and English Law. Rights, Responsibilities and the Place of Shari 'a, ed. Robin Griffiths-Jones, 2033. Cambridge: CUP 2013.

Women Living Under Muslim Laws. Knowing Our Rights. Women, family, laws and customs in the Muslim World. London: WLUML (First ed. 2003, Third Ed. 2006)

- Shah Bano and the Muslim Women Act, a decade on. (ed. Lucy Carroll). Grabels Cédex: WLUML, 1998.

Women's Research and Action Group. "Marriage and the Politics of Social Change in India's Muslim Communities." in Shifting Boundaries in Marriage and Divorce in Muslim Communities, ed. Homa Hoodfar, 168-187. WLUML: 1996 (np).

Wynn, Lisa. "Marriage Contracts and Women's rights in Saudi Arabia: Mahr, Shurut, and Knowledge Distribution." In The Islamic Marriage Contract. Case Studies in Islamic Family Law, eds. Asifa Quraishi and Frank E. Vogel, 200-214. Cambridge, Mass.: Harvard University Press, 2008.

Yamani, Maha. Polygamy and Law in Contemporary Saudi Arabia. Reading: Ithaca Press, 2008 .

Yassari, Nadjma. "Understanding and Use of Islamic Family Law Rules in German Courts: The Example of the Mahr." In Applying Shari 'a in the West. Facts, Fears and the Future of Islamic Rules on Family Relations in the West, ed. Maurits S. Berger, 165-187. Leiden: Leiden University Press, 2013.

Yazback, Mahmoud. "Minor Marriages and Khiyar al-Bulugh in Ottoman Palestine: A Note on Women's Strategies in a Patriarchal Society." Islamic Law and Society 9/3 (2003) 386409.

Yilmaz, Ihsan. Muslim Laws, Politics and Society in Modern Nation States. Dynamic Legal Pluralisms in England, Turkey and Pakistan. Aldershot: Ashgate, 2005.

Ziadeh, Farhat. "Equality (Kafa'ah) in the Muslim Law of Marriage: Problem of Sources." American Journal of Comparative Law 6 (1957) 503-17. 
Zomeno, Amalia. "The Islamic Marriage Contract in al-Andalus ( $10^{\text {th }}-16^{\text {th }}$ Centuries)." In

The Islamic Marriage Contract. Case Studies in Islamic Family Law, eds. Asifa Quraishi and Frank E. Vogel, 136-55. Cambridge, Mass.: Harvard University Press, 2008.

Zulficar, Mona. "The Islamic Marriage Contract in Egypt.” In The Islamic Marriage Contract. Case Studies in Islamic Family Law, eds. Asifa Quraishi and Frank E. Vogel, 231274. Cambridge, Mass.: Harvard University Press, 2008. 